Florida International University FIU Digital Commons

\title{
A Feminist Perspective on the Lack of Full Ordination for Burmese Buddhist Nuns
}

Darbee Nicole Hagerty

Florida International University, dhage004@fiu.edu

DOI: $10.25148 /$ etd.FIDC000289

Follow this and additional works at: https://digitalcommons.fiu.edu/etd

Part of the Buddhist Studies Commons, Ethics in Religion Commons, and the History of Religions of Eastern Origins Commons

\section{Recommended Citation}

Hagerty, Darbee Nicole, "A Feminist Perspective on the Lack of Full Ordination for Burmese Buddhist Nuns" (2016). FIU Electronic Theses and Dissertations. 2435.

https://digitalcommons.fiu.edu/etd/2435

This work is brought to you for free and open access by the University Graduate School at FIU Digital Commons. It has been accepted for inclusion in FIU Electronic Theses and Dissertations by an authorized administrator of FIU Digital Commons. For more information, please contact dcc@fiu.edu. 


\section{FLORIDA INTERNATIONAL UNIVERSITY}

Miami, Florida

A FEMINIST PERSPECTIVE ON THE LACK OF FULL ORDINATION FOR BURMESE BUDDHIST NUNS

A thesis submitted in partial fulfillment of the

requirements for the degree of

MASTER OF ARTS

in

RELIGIOUS STUDIES

by

Darbee Hagerty 
To: $\quad$ Dean John F. Stack

Steven J. Green School of International and Public Affairs

This thesis, written by Darbee Hagerty, and entitled A Feminist Perspective on the Lack of Full Ordination for Burmese Buddhist Nuns, having been approved in respect to style and intellectual content, is referred to you for judgment.

We have read this thesis and recommend that it be approved.

Oren Baruch Stier

Christine Gudorf

Steven M. Vose, Major Professor

Date of Defense: March 31, 2016

This thesis of Darbee Hagerty is approved.

Dean John F. Stack Steven J. Green School of International and Public Affairs

Andrés G. Gil Vice President for Research and Economic Development and Dean of the University Graduate School

Florida International University, 2016 
(C) Copyright 2016 by Darbee Hagerty

All rights reserved. 
ABSTRACT OF THE THESIS

A FEMINIST PERSPECTIVE ON THE LACK OF FULL ORDINATION FOR BURMESE BUDDHIST NUNS

\author{
by \\ Darbee Hagerty \\ Florida International University, 2016 \\ Miami, Florida \\ Professor Steven M. Vose, Major Professor
}

This thesis examines the position of Buddhist nuns (thila-shins) in contemporary Burmese society. The Sangha, a branch of the Burmese state, has disallowed them from seeking full ordination as bhikkhunis. Based on interviews and observations conducted in Myanmar in June-July 2015, the thesis examines the current socioeconomic status of thila-shins using a transnational feminist framework. It argues that Burmese Buddhist nuns are not simply passive victims of a patriarchal structure, but agents and actors within their own spaces who have their own agendas. The central questions are: How do thila-shins understand their social, economic, and religious position? How does ordination status affect thila-shins? Is barring thila-shins from seeking full ordination ethical according to Buddhist texts? Special emphasis is given to a rereading of traditional Buddhist doctrine on the issue of reviving full ordination for Buddhist nuns in light of concerns regarding agency present in Third World feminist movements. 


\section{ACKNOWLEDGMENTS}

If you can believe it, this was the hardest part of this thesis for me to write. I avoided it, wrote it, scrapped it and then wrote it again. How do you thank people you feel you'll never be able to repay? First, I have to mention my thesis advisor, major professor, and all around gifted teacher Dr. Steven Vose. He consistently allowed this thesis to be my own work while still steering me in the right direction when he knew I needed it. Thank you, from a place of the highest gratitude and respect, for your continuous help, encouragement, patience, and understanding with this(me). Beyond that, thank you for pushing me to do better when I thought I couldn't.

A very special thanks as well to my second reader, Dr. Christine Gudorf, who first sparked the passion that now sits deep within me for feminism and feminist theory. Her class was essential for my growth as an individual and a scholar, without which this thesis never would have been written. Her expertise and guidance was motivating as well as supportive while her roles as mother, professor, author were endlessly inspiring. Dr. Stier, my final committee member, was also instrumental in the writing process. He helped me to step outside of my comfort zone and develop a focus but more than that, helped me to feel comfortable becoming an authority on my subject (not an easy task for me).

I feel compelled to acknowledge those I worked with in Myanmar who transformed my fieldwork from something I was unsure I could achieve into an enriching, incredible experience. Daw Nang, Candasiri, U Panna Jota, Sandayee, Komala 
Terri, Sitala, Panna Dee, Candavara, along with all the nuns of Thila-Nyunt and others will always be held in my highest regard as their patience, readiness to clarify or answer questions, and above all their kindness was limitless. I doubt that I will ever be able to demonstrate my appreciation fully, but my eternal thanks are owed to them. It is not easy to offer yourself up to a stranger so purely and with so much trust, knowing full well that they will write about you and you may be misrepresented. It is my deepest hope that I transmitted their words and feelings in a way that is authentic to them. My connection to them, which served to be an integral part of my research, was all because of Dr. Hiroko Kawanami. Without her work on Burmese Buddhist nuns, there is no work of mine. The importance of her research and her readiness to put me in touch with contacts she knew on the ground in Mandalay and Sagaing cannot be overstated. I will be eternally grateful to her for that.

I must also acknowledge my fellow graduate student and friend Grisel D’Elena for her help in times of critical need, her unflinching support on issues relating to school as well as life, the inspiration she provided by existing as a dedicated mother and graduate student, and lastly her patience with me as a (younger) friend and colleague. Her heart is the biggest I’ve ever encountered and her encouragement guided me through my work when I was unsure if I would finish.

Finally, recognition must be given to my partner Jason and family, who always believed in me, rarely questioned me, and have been incredibly present and supportive throughout this entire process. Words will always fail when it comes to them, but in short, they are the reason I write. 


\section{TABLE OF CONTENTS}

CHAPTER

PAGE

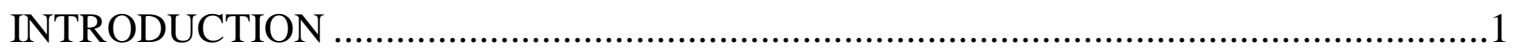

Transnational vs. Global Feminism ....................................................................... 4

Fieldwork in Myanmar ...................................................................................... 5

CHAPTER 1 A History of the Theravada Bhikkhuni Lineage: Disappearance and

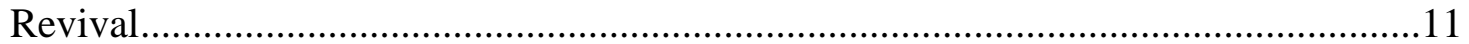

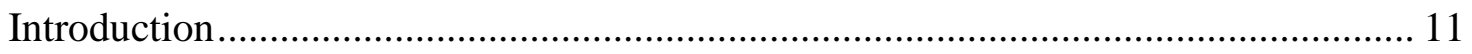

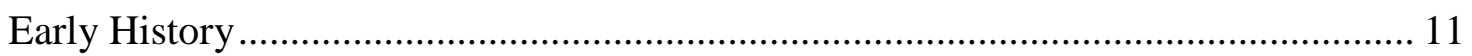

The Bhikkhuni Lineage Forms ........................................................................... 13

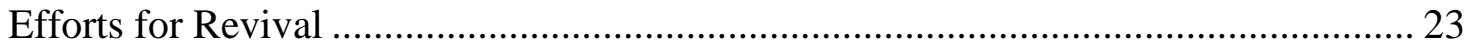

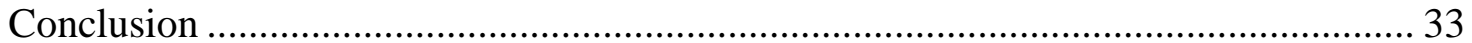

CHAPTER 2 Religious Mendicants in Myanmar-Burma: Comparing and Contrasting

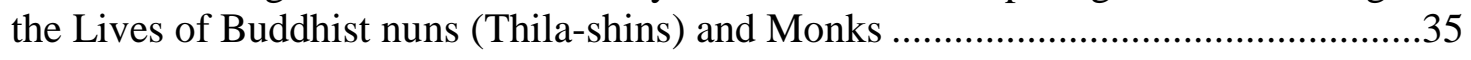

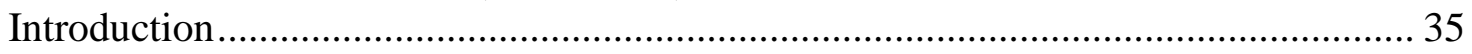

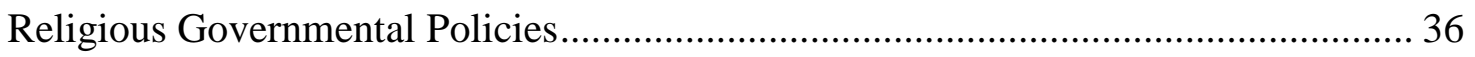

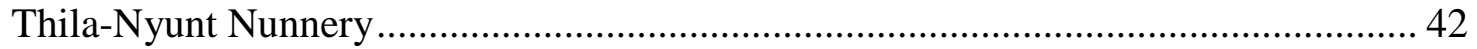

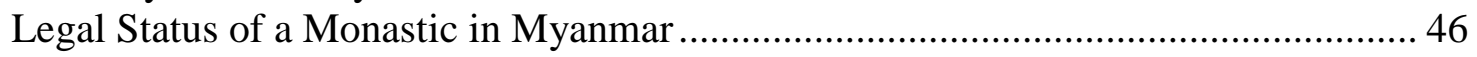

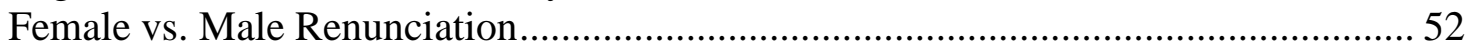

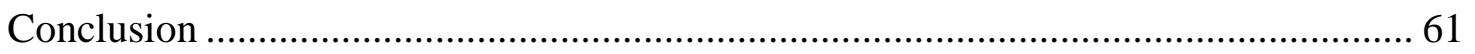

CHAPTER 3 Ethics and Equality in Burmese Buddhism: Full Ordination for Women ...63

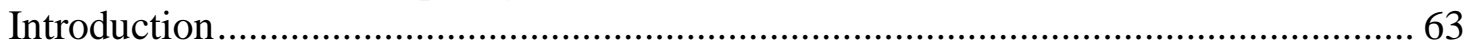

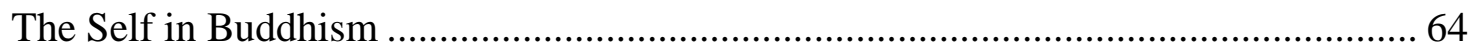

Attitudes of Monastics toward a Revival............................................................... 68

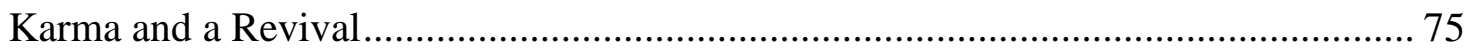

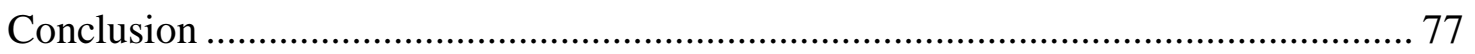

CHAPTER 4 Unexpected Conclusions: Thila-shins’ Spheres of Agency........................79

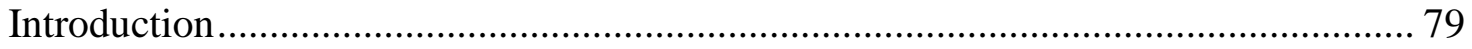

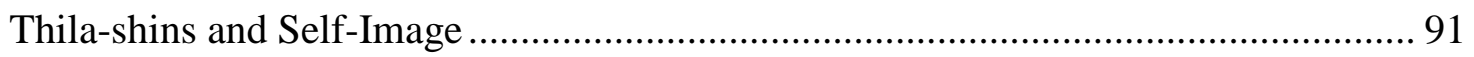

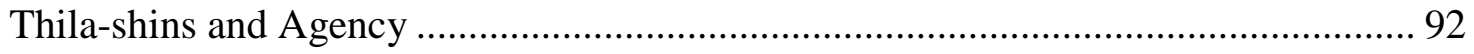

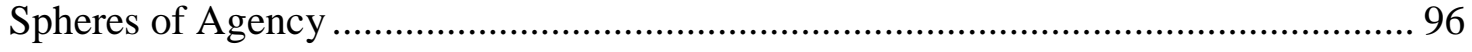

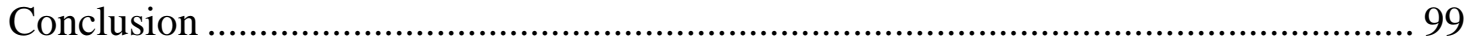

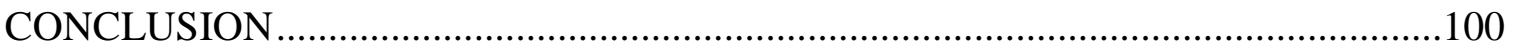

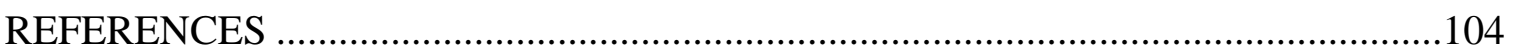




\section{LIST OF FIGURES}

FIGURE

PAGE

1. Across the river are the hills of Sagaing where much of my fieldwork took place.. 6

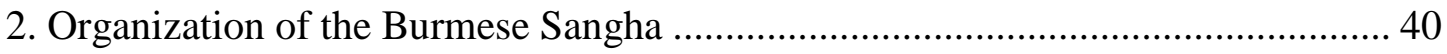

3. nuns sitting in the very back of the classroom at New Masoeyein Monastery....... 42

4. Sleeping area/hostel for the younger nuns of Thila-Nyunt ................................... 44

5. Partial image of New Masoeyein Monastery....................................................... 45

6. Candasiri in front of her hostel, Sagaing, Myanmar.......................................... 46

7. Novices relaxing during a midday break, New Masoeyein Monastery, Mandalay 56

8. Komala Terri of Thila-Nyunt serving food to novices on their alms rounds.......... 59

9. Young nuns of Thila-Nyunt nunnery carrying a donation of rice to the Kitchen... 88

10. nuns of Thila-Nyunt happily preparing meals for the nunnery ........................... 89

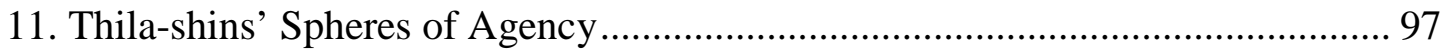




\section{INTRODUCTION}

Can we really understand different positionalities? Is it ethical for someone outside of a cultural group to speak of, for, or about that cultural group? Is feminism in its current form global? These, among others, are all questions I struggled with while completing this thesis. Before I had even chosen a topic for my thesis, I knew I wanted to conduct fieldwork. Before I conducted the fieldwork, it was very important to me to portray those I studied in a dynamic way that favored fair and accurate representations. The deeper this desire became, the harder it was to perform. It is essential for me to begin by describing the place from which I am writing. I am a white, middle-class woman from the United States, with a Western educational framework, and am acutely aware that I cannot speak on behalf of all women. Because of this position I am writing from, much of this thesis entailed a dismantling of my own viewpoints and ideas, including a deconstruction of stereotypical notions of what it means to be a woman.

I wish that I could say I was passionate about Burmese Buddhist women from the beginning of my academic career, but this would not be true. My thesis research fell serendipitously into my lap, without any planning or premeditation, and for this I will always be extremely grateful. I learned of Burmese Buddhist nuns in my first semester of graduate school, in a seminar on Theravada Buddhism. In the same semester, I was also taking a course on feminist theology. Neither of the courses spoke much about Myanmar, ${ }^{1}$ and it was by chance that I learned of the Burmese

\footnotetext{
${ }^{1}$ In recent years, there has been debate over whether to use "Myanmar" or "Burma" due to the first being a name given to the country by a military regime which did not consult the people and the second being a name given to the country during British colonial rule, an authority that also failed to consult the people. During my fieldwork, I found that some informants preferred the former while
} 
nuns' inability to become fully ordained. I cannot explain why this fact interested me so. Perhaps it was the happy coincidence of taking a course on the form of Buddhism that is practiced in Myanmar while simultaneously taking a course that examined feminist theory in religion. Whatever the reason, the more I researched Burmese Buddhist nuns, the more enthralled I became.

Theravada Buddhist women in Myanmar-Burma do not have the luxury of becoming bhikkhunis (nuns) because they are barred from becoming fully ordained by the Theravada Buddhist Sangha of Myanmar, which is an official branch of the Burmese government. Instead, aspiring nuns in Myanmar-Burma are referred to as "thila-shins" or "saya-leis." I use the word "nun" throughout this thesis, simply an English rendering of these three words. Thila, derived from the Pali word sila, refers to virtuous behavior or moral practice. Shin translates to "holds" or "possesses." Thila-shin roughly means "one who holds the dharma," or "a woman who observes the Buddhist code of morality;” but it does not refer to a person who is part of the sangha (monastic order) (Kawanami 1990: 3). Saya-lei, perhaps diminutively, translates to "little” or "small teacher.” Because thila-shins are not fully ordained, they fall under the category of "upasikas" (laywomen) in traditional Buddhist classification. Functionally, however, they are not productive householders but are instead considered almswomen who are dependent on the laity. They neither receive the benefits of being in the monastic community nor the luxury of living as freely as the lay community. It may be helpful here to dive briefly into semantics, as I did notice different members of society used the words differently and being precise in

others preferred the latter while others still used the two together. For this reason, I will use the terms Myanmar, Burma, and Myanmar-Burma interchangeably throughout this thesis, as all three are designations used by inhabitants of the Southeast Asian country. 
language can mean understanding language in a deeper way. Interestingly, monks seemed always to use "saya-lei" when referring to Burmese nuns. Laypeople (men and women) seemed to always use thila-shin, while Burmese nuns themselves would simply use the word "nun," despite the fact that they are not technically nuns. This is significant in light of what I will discuss in Chapter 4.

If the religion and government of a nation sends a clear message that women cannot attain the highest form of spiritual development offered by that religion, how does this affect women and their agency in their own (spiritual) pursuits? This thesis explores the socioeconomic status that thila-shins occupy in Burmese society as well as how their ordination status affects them individually using a transnational feminist conceptual framework. This framework, which will include several important transnational feminist thinkers such as Chandra Talpade Mohanty (2003), Uma Narayan (1997), and Angela Woollacott (2006), will work not only to unpack the significance of the fact that women's movements across the globe are different, but will also show how the thila-shins of Burma participate in their own movement that is a localized and specific response to their situation. Much of the literature available describes thila-shins as occupying a marginalized space in society due to their “betwixt and between” religious status (Kawanami 2013).

The justification for their liminal status can be found within their lack of ordination, the argument for which is heavily rooted in a rule that was laid down by the Buddha (according to textual tradition). The rule states that any woman wishing to be ordained must be ordained by an experienced bhikkhu and an experienced bhikkhuni. Because there is no longer a bhikkhuni lineage, no there are no current 
bhikkhunis who can assist in an ordination ceremony to ordain additional bhikkhunis into the lineage. This is a mere technicality at best, but one that has kept women from ordaining since at least the seventeenth century, possibly even before then. Arguably, it has held strong due to the power of religious doctrine as well as to a long history of patriarchy within the tradition. The rule presents a kind of conundrum, one that the spiritual Burmese men of Buddhism would never have to face.

\section{Transnational vs. Global Feminism}

I use the phrase "transnational feminism" as opposed to "global feminism" because I feel it more accurately describes the method with which I am approaching this issue. While the two words could arguably be used interchangeably, and global feminism surely includes the notion that any female essentialism is something to move away from, I believe that by using "transnational” instead I am already describing the way I am looking at the issue of full ordination for women in Myanmar. It suggests intersectionality, the idea that there are particular forms of intersecting oppressions, such as that of sex and nation. Intersectional paradigms remind us that oppression is unable to be reduced to a single, fundamental type but rather they work together in creating or producing injustice. It is more of a methodological term while "global" is much more descriptive of place and concerned with the feminisms around the world. The thesis also moves between Marxist and socialist feminism as I was increasingly trying to understand women's subordination in the Burmese sangha in a coherent and systematic way that integrated sex, class, and other components of identity.

This project was a lesson in recognizing the importance of the idea that women are not dealing with the same issues, their lived experiences are not the same, 
and thus they respond differently to their unique social environments. The things I wanted for thila-shins often differed from what they wanted for themselves. Elizabeth Spelman articulates this point quite eloquently: "If...I believe that the woman in every woman is a woman just like me, and if I also assume that there is no difference between being white and being a woman, then seeing another woman 'as a woman' will involve seeing her as fundamentally like the woman I am” (Spelman 1988: 13). In other words, I needed to take the differences between these women (and all women) and myself seriously. Though this seems obvious, work on Third World women often reduces their human agency. It seems that in much of the social sciences, research subjects can be treated as if they have little or no individual history, no feelings or ambivalences, no self-knowledge and even no individuality. It cannot be stressed how imperative it was for me to not make this mistake.

\section{Fieldwork in Myanmar}

All quotations from saya-leis, monks, and laypeople from Myanmar that appear in this thesis were collected during my fieldwork in June-July 2015. I took all photographs used in this thesis in the same period. At the end of May I flew to the city of Mandalay, Myanmar and alternated between there and the city of Sagaing for the duration of my stay.

Towards the end of my fieldwork, I was given the opportunity to temporarily ordain as a thila-shin myself, wear the robes of a Burmese Buddhist nun, and live for a time inside a local nunnery alongside my Burmese sisters. Thila-Nyunt, located in the hills of Sagaing (pictured in Figure 1 below) on the western banks of the Irrawaddy River, is the name of the nunnery I called home as well as the place where 
many of my interviews and much of my data collection took place. I mention this in the introduction because I believe it altered my relationship to the research as well as the outcome of the research and this, at least, is relevant. I do not go into detail of my individual experience because I feel it is neither productive nor necessary for the thesis as a whole. I do, however, mention aspects of my time as a thila-shin that deepened my understanding of the current socioeconomic status of a thila-shin in Burmese society and their relationship to their ambiguous religious position. Had I not lived inside Thila-Nyunt, I likely would not have come to the conclusions that occupy the last chapter of this thesis.

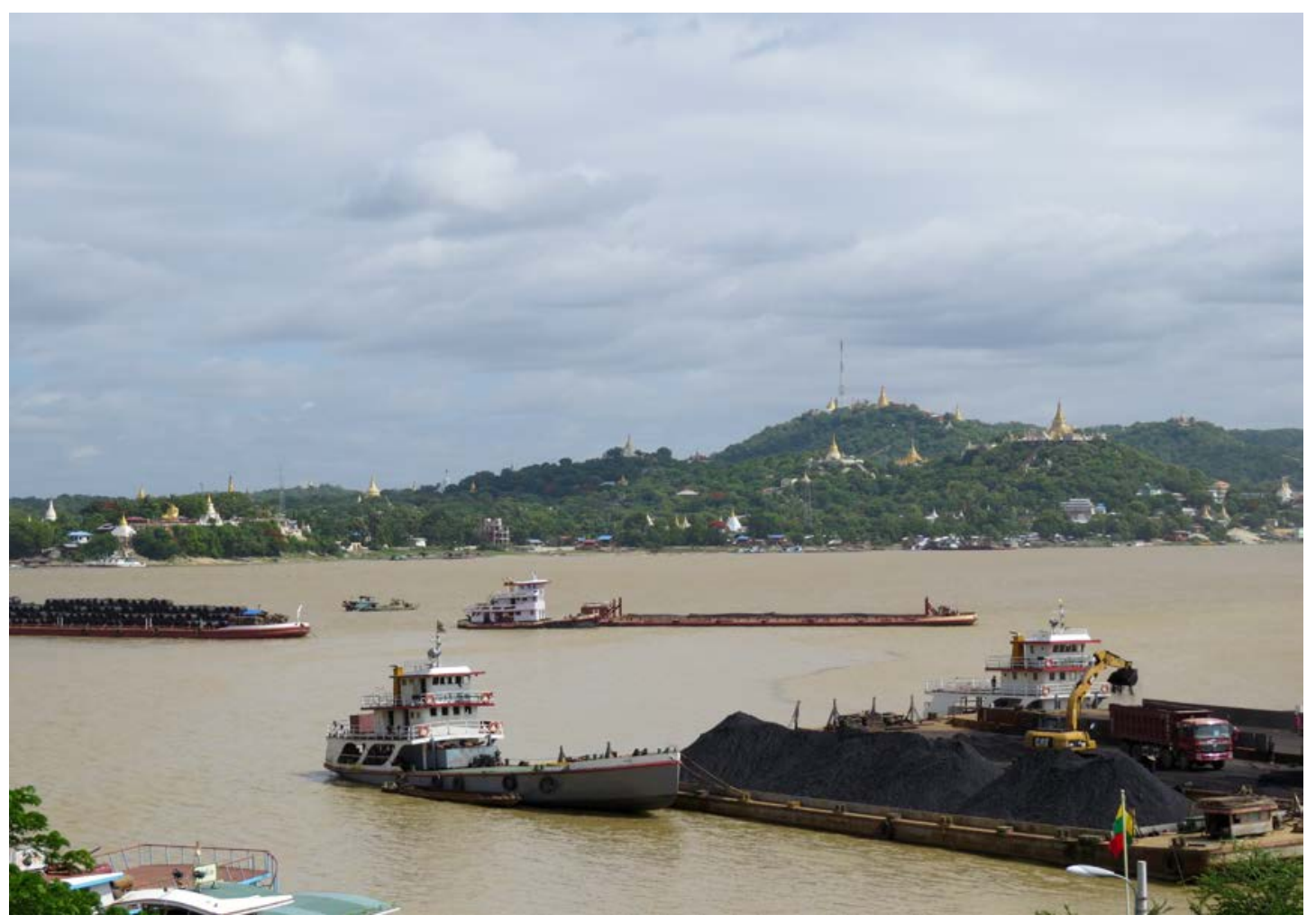

Figure 1. Across the river are the hills of Sagaing where much of my fieldwork took place

Chapter 1 puts forth a complete history of the bhikkhuni lineage, not just in Myanmar, but dating all the way back to the time of the Buddha. This proved to be 
more than difficult (not surprisingly as it spans such a large amount of time in history) due to two historical holes littering the past of the Theravada Bhikkhuni Sangha. The first hole is from around 100 BCE to 300 CE and the second is from about the twelfth century onward. Little to zero information on Theravada Buddhist nuns exists from these two periods, which meant I had to piece together many different pieces of historical information from numerous sources to try and understand the reasons behind the disappearance of the Burmese lineage for bhikkhunis. Understanding the history of the lineage, in my opinion, is essential for understanding the context for revival, another important element of this first chapter. Efforts for revival of a Theravada Bhikkhuni lineage have been successful in Sri Lanka, which the first chapter shows had close relations with Myanmar-Burma throughout history. This is significant as Myanmar, at one point in time, sent bhikkhus to Sri Lanka to aid in reviving their lineage. The question must be asked, why were bhikkhunis not sent as well? Furthermore, if Theravada history has evidence of members of its monastic community travelling from one place to another in order to revive a lineage, why would present day thila-shins not be encouraged to travel to Sri Lanka to receive their full ordination now? The easy answer to the first question is to assume that patriarchal hierarchies and structures neglected to consider the importance of sending bhikkhunis. The answer to the second question brings us back to the rule: an experienced bhikkhuni must be present to ordain a new bhikkhuni into the sangha. I use analyses of Buddhist texts and arguments by Bhikkhu Bodhi to examine the legitimacy and authoritative nature of this rule. I close with a call to 
reinterpret the Buddhist texts in order to discern exactly how best to go about reinstating a bhikkhuni lineage.

Chapter 2 compares and contrasts the lives of Buddhist nuns and monks in Myanmar, delving into religious governmental policies that monastics are required to follow as well as the seemingly fluid status of a thila-shin where the government is concerned. For example, those who are members of the monastic community are not allowed to vote in political elections. Technically, thila-shins are not part of the monastic community, yet they are not allowed to vote. The government picks and chooses when they want thila-shins to be included as monastics, which is indicative of the idea that much more than Buddhism surrounds the issue of full ordination for women in Myanmar. I examine how this fluid position can be both difficult for and potentially damaging to thila-shins. This chapter also explores sexuality within Buddhist texts, attempts to understand how thila-shins understand their femininity as it relates to their Buddhist practice, and considers the religious transactions monastics have with society. This chapter, perhaps more than any others, makes clear how the idea that only women have a gender is very strong in the collective Burmese conscious. It also makes clear that, though women's productive labor is of evident importance to the basic structure of the monastic community, they are consistently viewed as sexualized beings who are unworthy of attaining the highest form of spiritual achievement. Foucault's biopower or biopolitics is useful here, as it helps to understand how state power can extend to other institutions and exercise power over lives and bodies, influencing relations and interactions between groups of people. 
Chapter 3 briefly explores the idea of the "self" in Theravada Buddhism in an effort to discuss the seemingly paradoxical nature of disallowing women to fully ordain while simultaneously advocating for the idea of "no-self." While the "self" does not matter, it seems that the body does. I also move through attitudes of thilashins and monks toward a revival of the bhikkhuni lineage, arguing that not supporting a revival or reinstatement could result in the accruement of negative karma according to Buddhist doctrine. I discuss karma and the criteria for a wholesome and unwholesome action, advocating for the idea that the decision to disallow the revival of a bhikkhuni lineage in Myanmar implicates all who support it. This is, in a way, an attempt to use historical texts to combat historical texts. What is more important, following the ancient rules or accruing good karma? Where a revival of the lineage is concerned, I argue that the Burmese Sangha cannot do both.

Finally, Chapter 4 discusses the daily activities and everyday concerns of thila-shins along with briefly covering my own experience as a thila-shin and the positive aspects to the liminal status of Buddhist nuns in Burma. Perhaps most important, and my unique contribution to the literature available on Burmese Buddhist nuns, is the discussion of agency and resistance as they relate to feminist movements in this chapter. I propose a theory of spherical agency: thila-shins possess high levels of agency in certain spheres of their lives but not all. Agency in one sphere does not guarantee agency in another, and my research made clear the need for thila-shins to foster agency in all spheres.

There were many times in my field and textual research that I encountered what seemed like intransigence in regards to full ordination for women. In spending 
time with the saya-leis of Myanmar, it was clear that (for many of them) the possibility of becoming a fully ordained bhikkhuni was not one that was ever entertained in their minds. It is my hope that, with this and other works, thila-shins one day secure the ability to become fully ordained like their male counterparts. 


\section{CHAPTER 1}

\section{A History of the Theravada Bhikkhuni Lineage:}

\section{Disappearance and Revival}

\section{Introduction}

Although the majority of Buddhist scholars can agree that there was an order of nuns at the time of the Buddha, that there were enlightened women practicing the dhamma, not all scholars can agree on what happened to this lineage of nuns or where it spread before it died out. Where some make the argument that it did, in fact, reach Burma, others say this evidence is inconclusive at best. In order to understand the context of the revival of a Theravada bhikkhuni lineage, it is essential to understand the history of that lineage including its embryonic and flourishing stages before it disappeared from discourse. If we want to make an argument for revival, we must understand the lineage in its entirety. This chapter will work to provide a historical narrative of the beginning and end of the Theravada female monastic lineages (with a focus on Myanmar) while examining Buddhist textual sources on female monasticism.

\section{Early History}

A history of the Theravada female monastic lineage would seem incomplete without the famous Pali account of the Buddha assenting to a lineage of bhikkhunis after the urging of one his closest disciples, Ananda. Though the story is not history but rather strong textual tradition, I include it because traditional Theravada Buddhists employ it when writing their narrative constructions of self. One can find this story in the Cullavagga, which is also considered the interpretive source of the bhikkhuni origin. In it, the Buddha agrees to allow an order of nuns but insists that because of this 
allowance, his teachings will last a much shorter time than they originally would have without the bhikkhuni order. He warns, "But since, Ananda, women have gone forth... in the dhamma and the discipline proclaimed by the Truth-finder, now, Ananda, the Brahman-faring will not last long, true dhamma will endure only for five hundred years” (Horner 1930: 356). This was an incorrect prediction as Buddhism has thrived for much longer than five hundred years, order of nuns and all. However, of all the passages and ancient scriptures, it is this short one that many in the current day use to argue that the Buddha never intended for an order of bhikkhunis to exist in the first place and thus never truly wanted one. Some, according to Bhikkhu Bodhi (2012: 1), even go so far as to use it to justify their refusal to support efforts of Buddhist women to re-establish the lineage. This passage and the argument against using it to justify disallowing women to revive their lineage will be returned to later in the chapter.

No matter his seemingly hesitant attitude toward the situation, the Buddha accepted the nuns because he asserted that they, too, had the capacity to achieve full enlightenment. The dispute over whether women can or should be in the monastic order seems to be a kind of unfinished puzzle where the missing piece has been sitting directly in front of us the whole time. This, of course, is a liberal reading of the history of Theravada Buddhism. For the purposes of this chapter, what can be stated without question is that the Buddha allowed women to be included in the monastic community, assented to their full ordination, and asserted that they were capable of the highest spiritual achievement. Theravada Buddhist scriptures have valued women 
individually in texts like the Therigatha (where we see several accounts of women attaining nibbana) and collectively as an essential part of the sangha.

\section{The Bhikkhuni Lineage Forms}

Most assume that the Buddha’s foster mother, Queen Pajapati Gotami, was the first woman he ordained and that she became the first bhikkhuni. However, recent scholarship suggests evidence of bhikkhunis prior to Pajapati’s ordination. ${ }^{2}$.

Exploration of this would be a separate thesis all its own and something that is not useful for this research. Still, the fact that there were other accomplished Buddhist women ready to enter the order other than just the Buddha's foster mother is a testament to the history of women and their enthusiasm toward the tradition. They have always been present. If the traditional account is accepted (and many do believe that whether she was first or not, Pajapati was ordained and subsequently her followers were as well) then the Bhikkhuni Sangha that developed and formed after the ordination of Pajapati (and her five hundred followers) existed in India until at least the eleventh century (Lekshe Tsomo 2004: 119). This is where the first discrepancy comes into play; Blackburn asserts that formally institutionalized female monasticism diminished after the tenth century (Blackburn 2001: 25) while others have even suggested that this lineage went into the twelfth century (Sarao and Singh 2007: 161). No matter the date that scholars use as the time when female monasticism disappeared, the reasons behind this disappearance are even more ambiguous.

\footnotetext{
${ }^{2}$ Although the Cullavagga provides a context in which Mahapajapati becomes the first bhikkhuni, there is evidence otherwise in the Mahaparinibbana Sutta, Dakkhinavibangha Sutta and the Therigatha. (Williams 2000:167-173) (Krey 2010: 39-64).
} 
What can be helpful is going back in time to when we know the lineage was still in existence and building up from there. What can also be helpful is asking not about the entry of Buddhism into a region, but rather when, how, by whom, from which section of India, and to what part of Southeast Asia. This last question, though, sometimes involves nationalistic pride. Each country (including, perhaps especially, Myanmar) wants to claim the position of becoming Buddhist first, but we would do well to remember that the introduction of Buddhism did not happen in a single moment, not even as a single act. Buddhism was a living faith that flourished, thrived, and developed in India and surrounding areas for more than fifteen centuries (Assavavirulhakarn 2010: 45). The introduction of the female monastic lineage as well as its demise, then, was a long process that occurred over time and with the influence of other religions and cultures of that age along with Buddhism's own developments. It is likely that there were multiple introductions of Buddhism to Myanmar, perhaps even different schools of Buddhism introduced at different times. It is even possible that Myanmar did not even adopt Buddhism directly from India, a notion that is not popular among Burmese historians, who prefer to think of the monastic lineage of their country as one that is very close to the one that the Buddha himself created. Buddhism moving into Myanmar, and Buddhism moving into the lives of Burmese women, is better understood not as an insolated event, but as a dynamic approach that included the overall process of Indianization in which trade, missions, and pilgrimage - as well as initiatives from within Southeast Asian culture itself - all played important roles (Assavavirulhakarn 2010: 45). 
There is, however, solid evidence of an introduction of Buddhism from India during the Maurya Dynasty to Sri Lanka. This is important for the task at hand because there is substantial evidence that supports a relationship between the Sri Lankan Theravada monastic lineage and the monastic lineage in Myanmar throughout history. The Emperor Asoka, an important ruler of India (arguably one of the most important rulers in history) ruled from around 269 BCE to 232 BCE. It may be important to note here that, though traditional dating of the Buddha has him living in the $6^{\text {th }}$ century BCE, new information has some scholars dating the Buddha as living in the fifth century and even into the fourth, about 60 to 80 years before the Maurya Dynasty began. Asoka was a staunch supporter of Buddhism and there is evidence that he sent missionaries from his kingdom to spread the teachings of the Buddha. Sri Lankan chronicles attribute the introduction of Buddhism into Southeast Asia to the mission sent from India during Asoka’s reign. Sinhala monks completed and preserved the Pali chronicles and these, along with other inscriptions and extensive archaeological remains, make it possible to piece together a comparatively full picture of Theravada Buddhism in Sri Lanka from the beginning (Sarao and Singh 2007: 123).

There are two major epigraphic pieces of evidence from early Indian Buddhism: the Asokan edicts and the reliquaries at Vedisa (Mohr and Tsedroen 2010: 32). Incredibly, and with staggering consistencies, both of these confirm the evidence found in the Sinhalese Vinaya commentary. To scholars' astonishment, the Vedisa inscriptions mention several of the monks who also appear in the Sinhalese Vinaya commentaries. The same names appear in each text as missionaries who were sent 
after the "Third Council" to spread the teachings of the Buddha. These names being found in sources that resided in such widely separated geographic areas is regarded by many Buddhist scholars as one of the bedrock findings of modern Buddhist studies and rightfully so (Mohr and Tsedroen 2010: 32). If one accepts this account, then the introduction of Buddhism would have been very straightforward, simple even, involving two monks travelling to a region and converting those who lived there. Though there is evidence, it is important to remember that historically speaking, this introduction of Buddhism was probably more complicated than it seems.

As stated above, it is important to discuss these Sri Lankan chronicles, not just because they are one way of understanding the spread of Buddhism from India to other countries, but also because they lead us in the direction of uncovering the advent of Buddhism in Myanmar-Burma and thus painting a clearer picture of the female monastic lineage. According to the tradition preserved in these chronicles, two monks by the names Sona and Uttara travelled to a place called Suvannabhumi to spread Buddhist teachings during the rule of Asoka. There is much dispute over the precise area to which Suvannabhumi refers. When discussing the history of Buddhism in Burma, it cannot be stressed how very important it is to understand the geographical significance of this ancient region. Some scholars identify Suvannabhumi with Burma or parts of Burma (Sarao and Singh 2007: 163), while some place it in central Thailand and others go with a broad interpretation of the whole of Indo-China. The majority of scholars agree on only one point: Suvannabhumi was situated in Southeast Asia (Assavavirulhakarn 2010: 49). This is where agreement ends and even where the nationalism issue comes into play. The 
Burmese believe this ancient region to be Burma. For those who are Thai, Suvannabhumi refers to a place in Thailand (Mohr and Tsedroen 2010: 33).$^{3}$ Some argue, and I tend to agree, that it should be treated as a directional term and not a regional one, simply meaning “east of India” (Assavavirulhakarn 2010: 50). Perhaps even more properly, the region of Southeast Asia without clearly defined borders corresponding to contemporary national ones. I would argue that, while Suvannabhumi could refer to what is now Burma, it probably refers to a whole region that was comprised of different cities and centers with far-reaching boundaries that varied over hundreds of years.

Even though there is much evidence to suggest that this ancient place is referring to a whole region, for the purposes of this thesis, it is important to state the arguments that place Suvannabhumi somewhere in modern day Burma or even to include modern Burma within the ambit of Suvannabhumi. The Kalyani inscriptions, which date to ca. $1476 \mathrm{CE}$, were found in the Mon country, a region in the southeastern part of Burma. Suvannabhumi is what the Burmese people understand as today's Lower Burma and where members of the ethnic Mon group still reside (Lekshe Tsomo 2014: 40). What is curious, however, is that the mission of these two monks that Asoka putatively sent to Burma appear in neither the Burmese records, nor in any of the inscriptions of Asoka himself. Another inscription, from around the third century CE, was found in the second apsidal temple in the ancient Indian city of Nagarjunikonda. This inscription refers to a Buddhist association of the Cilatas. Scholars have suggested that Kirata, which is the country of Cilatas, was Arakan and

\footnotetext{
${ }^{3}$ Interestingly, one of Thailand's main airports, Bangkok International Airport (BKK), is also known as the Suvarnabhumi Airport, a clear declaration that this ancient place has its roots in Thailand.
} 
lower Myanmar, or where the Mon country is found (Sarao and Singh 2007: 164).

Furthermore, considering Chinese writers in Chin-lin (the Frontier of Gold), Buddhism was known about 250 BCE in old Prome. (Sarao and Singh 2007: 164). Old Prome refers to somewhere in central Myanmar: the ruins of the city lie in modern day Hmawza. This information or suggestion by the Chinese writers becomes all the more important when considering the Nagarjunikonda inscription. If one also considers the close proximity of India to Myanmar on top of the existence of not so strenuous land routes between the two of them even before the Christian era, the possibility should not be excluded that the Buddha's teachings found their way to Burma even before these suggested dates.

Regardless of whether the missionaries of Asoka made it to Burma or not, from the fifth centuries onward there are definite records that prove not only the presence of Theravada Buddhism, but its flourishing in Burma in the old kingdom of the Pyus known as Sirikhetta with its capital near Prome (Sarao and Singh 2007: 164). In fact, during the Pyu Period, Chinese sources refer to bhikkhunis in Burma. A renowned scholar of Burma, Gordon H. Luce, translated and quoted from these texts: "When they come to the age of seven, both boys and girls drop their hair and stop in the monastery where they take refuge in the Sangha. On reaching the age of twenty, if they have not awakened to the principles of the Buddha, they let their hair grow again and become ordinary townsfolk” (Luce 1969: 41). From this passage, we can discern that women at the time could remain in the monastic community if they desired to or if they "awakened," which suggests that full ordination was available to them. It is important to mention that evidence of other schools of Buddhism (separate from 
Theravada) was also found in the ruins of Prome. The remains show Sanskrit forms of Buddhism present in the area, suggesting that the religion had come under the influence of new or different streams of thought (Sarao and Singh 2007: 164). The Sanskrit form of Mahayana probably came from places like Bihar and Bengal. This is significant because surely both (possibly even more than two) schools of Buddhism were ordaining men and women at the time. Surely, each form and school had a discourse with and thus influenced the other. Though Burmese Buddhists would tell you that they are a strictly Theravada country, this was not always the case, and makes the argument against revival of the bhikkhuni lineage even more complicated and faulty. ${ }^{4}$

According to a tradition mentioned in the Glass Palace Chronicle (a text of the Kings of Burma), Buddhaghosa went to Sri Lanka in the fifth century CE from his birthplace in Myanmar in order to obtain copies of the Tipitaka that he could transport back to his home country (Sarao and Singh 2007: 165). He reportedly brought with him back to Myanmar a copy of Kaccayana’s Pali grammar and translated it into Burmese. As Pali was the common language between Theravada countries, Buddhaghosa's translation of this book and the Sinhalese Commentaries made the texts available to Buddhists studying in Burma. Some even credit Buddhaghosa's voyage for the development of Theravada Buddhism in Burma.

\footnotetext{
${ }^{4}$ To clarify, several Burmese bhikkhunis (one of which who will be discussed later in this chapter) have travelled to Sri Lanka to receive their full ordination. Because the Sri Lankan bhikkhuni lineage was reinstated with the help of some Mahayana bhikkhunis in 2007, Myanmar does not recognize the current lineage as authentically Theravadin and so does not recognize it at all. This is why the presence of other forms of Buddhism in Myanmar history causes the argument against the revival to be more complicated and perhaps faulty. Myanmar was not always authentically Theravadin, even Myanmar's lineage was at one point in time in close contact with other forms and schools of thought of Buddhism.
} 
Around this same time, a Chinese text compiled in 520 CE documents the journey of two groups of Sinhala nuns from Sri Lanka to China in an effort to introduce the lineage of bhikkhuni ordination (Lekshe Tsomo 2004: 121). According to the text (Biographies of Buddhist nuns), the first group, led by a Sri Lankan nun named Devasara, arrived in China by 429 CE. Four years later, at a monastery in Nanjing, the Sinhalese bhikkhunis ordained more than 300 Chinese nuns (Lekshe Tsomo 2004: 121). Until this time, these Chinese nuns had only received ordination from monks and this higher ordination was highly significant in terms of empowerment and recognition. This enabled them to establish their own Vinaya tradition, gain followers, collect support, and eventually carry on the tradition of full ordination for women to nuns in Vietnam and Korea (Lekshe Tsomo 2004: 121). I bring this up for two reasons. The first is that it is one of two examples in Theravada history of nuns or monks travelling to another country in order to revive or introduce a lineage. The second is because until very recently (in 2007) Sri Lankan nuns were not fully ordained while Chinese nuns were. Because nuns of the Chinese tradition are fully ordained, they live by high standards of conduct, receive adequate education and training, and enjoy ample support from their followers (Lekshe Tsomo 2004: 121). In stark contrast, the Sri Lankan Bhikkhuni Sangha, which provided the context for full ordination for nuns in China, completely disappeared in Sri Lanka by the twelfth century (similar to the Burmese Bhikkhuni Sangha). To this day, nuns around the globe who trace their traditions and lineages to the Chinese Buddhist tradition observe the Dharmagupta Vinaya, when in reality, their history lies in the Theravada tradition. This is just to say that perhaps these two traditions are closer than they 
think, and acknowledging the ordination of one in the other tradition would not be as far fetched as one might assume.

It was clear that in the eleventh century CE, Sri Lanka and Burma had friendly relations and, for Sri Lanka in particular, it was quite a difficult time. In the year 1017, Anuradhapura fell to Chola invaders from the south of India. It is not certain, but many credit to this event the disappearance of the orders of both nuns and monks in Sri Lanka. King Vijayabahu (1010-1111 CE), who made a great effort to care for and protect the Buddhist tradition in Sri Lanka, discovered that few Sinhala monks had travelled to Burma to seek refuge (Lekshe Tsomo 2004: 120). In 1071 CE, he dispatched a religious mission to Burma and invited the monks to return to Sri Lanka where they restored the Bhikkhu Sangha. King Aniruddha (of Burma) readily responded to his friend's request and immediately sent 20 ordained monks as well as various Buddhist texts. Several, varied inscriptions of the time of King Vijayabahu prove with no contention that the Sri Lankan Sangha was re-established and reformed with the help of Burmese monks (Sarao and Singh 2007: 170). ${ }^{5}$ Later, on two separate occasions when natural disasters and conflict caused the demise of the bhikkhu order, monks were invited from Burma again to aid in re-establishing and reviving the Sri Lankan Bhikkhu Sangha. (Lekshe Tsomo 2004: 120).

When reading these historical accounts, one cannot help but marvel at the complete lack of mention of the bhikkhuni lineage. No source that I have found gives any clue as to what happened to the Sri Lankan Bhikkhuni Sangha nor does any

\footnotetext{
${ }^{5}$ It should be noted that though the two kings were in good standing with one another, King Aniruddha did not send any troops to aid Vijayabahu against the Chola invaders when he was asked. He instead sent many ships in return bearing costly gifts. It appears that he did not want to cross swords with the Chola as they were very powerful at this time and Burma was enjoying a time of peace (Sarao and Singh 2007: 169).
} 
source mention why nuns were not also sent along with the monks to Sri Lanka. One wonders whether the bhikkhuni lineage in Myanmar had already died out and so there were no nuns to send, or perhaps neither King Vijayabahu requested nuns to be sent nor did King Aniruddha see it fit or meaningful to send them. Just as women have had strong spiritual pursuits in Buddhism throughout history, it seems the men in their tradition have repeatedly neglected to value these pursuits.

Later on, during the Pagan period of the eleventh to thirteenth centuries, there are inscriptions that refer to female religious mendicants in Burma, and some scholars argue that they were fully ordained bhikkhunis (Lekshe Tsomo 2014: 41). Little is known about how this lineage died out (similar to the Sri Lankan lineage, though scholars are even more unsure of the cause behind the Burmese bhikkhuni lineage disappearance), though some attribute its disappearance to the devastation Pagan underwent by the Mongol emperor of China in 1298 CE (Lekshe Tsomo 2014: 41). Burma was in a state of political turmoil following this event for several centuries, and we can only guess that this is the reason for the disappearance of the bhikkhunis. It seems as though the bhikkhu lineage kept on thriving, but ceased to mention any women who were part of the monastic community after this time period. Interestingly, in my research, I have found two time periods that prove to be holes in the history of Theravada Bhikkhuni sanghas. The first is from around 100 BCE to $300 \mathrm{CE}$ and the second is from around the twelfth century onward. Again, one is compelled to ask the reasons behind this. What happened to these nuns? Why was there no attempt to revive the order of nuns in Sri Lanka or Burma? This question rings especially loud in the case of Sri Lanka because the order of monks and nuns 
died out together and the place from which the bhikkhu lineage was restored had a thriving bhikkhuni lineage at the time. If Burmese monks were sent, why were Burmese nuns not sent alongside them? If the bhikkhuni lineage had already died out by this time, what happened to them? If such a group did exist, why did King Vijayabahu not request their return to Sri Lanka as well? If they were asked, did they choose not to go? If they stayed, would the lineage not have been even stronger in Burma? All of these questions are intriguing, but unfortunately there are very few documented answers for them. What we can deduce from the history of Buddhism is that there are no holes in the history of the bhikkhu lineages, a clear indicator, perhaps more than anything else, of how the decision as to whose spiritual path is valued is a deeply gendered one.

\section{Efforts for Revival}

Answering the above questions is not absolutely necessary to understand the context for revival. What we know is enough. For example, I have shown several instances in Theravada history, even instances in Burmese Theravada history, where monks have travelled outside of their native countries in order to re-establish or revive a lineage for bhikkhus. Why would bhikkhunis not be given the same opportunity, and furthermore, why would the Sangha not request it to be done as was requested for the bhikkhu lineage?

The tradition that exists currently for women in Burma formed during the reign of King Mindon (1825-1878), when the first evidence of influential thila-shins 
comes onto the scene, and this order still thrives today (Lekshe Tsomo 2014: 41). ${ }^{6}$ Sadly, because the thila-shins are not considered fully ordained bhikkhunis, they are given considerably less respect, support, alms, and veneration than monks. Moreover, the official religious organization of Burma (the Ministry of Religious Affairs) is ruled by the State Sangha Council of Myanmar (Lekshe Tsomo 2014: 41). This council, which will be discussed extensively in Chapter 2, consists of 47 monks who have a legal right to decide and foresee the regulations of the monastic community. It cannot be stressed how little say thila-shins have in any of the decisions made for Buddhism in Burma in general and in their individual spiritual pursuits. Regardless of how crucial their services are to the preservation of the Buddhist community in Myanmar, their voices are not included in the decision-making process and their education is not a priority.

Arguments for disallowing a revival of the bhikkhuni lineage (in Burma or Thailand: the lineage has already been revived in Sri Lanka) use several different key passages from Buddhist texts. However, as Bhikkhu Bodhi shows us, if you read the texts carefully, there is no reason for dispute. The dual-sangha ordination, the standard for ordination ceremonies today, which involves both a bhikkhu and a bhikkhuni to be present, was never intended to apply under all circumstances without exception. Under exceptional circumstances the Bhikkhu Sangha alone can ordain women as bhikkhunis, based on the Buddha's statement: "I allow you, bhikkhus, to ordain bhikkhunis” (Bodhi 2012: 2). The Buddha never rescinded this allowance.

\footnotetext{
${ }^{6}$ It is interesting to note that the two first nun teachers whose names appear in the official record of Myanmar history were both originally Manipurians who were brought over to Myanmar as infant prisoners of war during the time of its aggressive conquests of neighboring territories. (Kawanami 2013: 160.)
} 
Before the Buddha’s great passing away, he declared that should the sangha find some of the minor rules troublesome in the future, they could be eliminated (Mohr and Tsedroen 2010: 154). Ananda, the same monk who advocated for the allowance of the first order of nuns, is characterized in this passage much like he is in other Buddhist stories. ${ }^{7}$ He apparently failed to either acquire or recall the necessary details from the Buddha concerning disciplinary procedures, procedures that the Buddha suggested the sangha could do away with after his death if it was so desired. When the sangha met and the First Council was held ${ }^{8}$, they could not decide which were the minor rules and which the major (Ananda was blamed for this), and Mahakassapa proposed maintaining all of them without new additions or subtractions (Mohr and Tsedroen 2010: 154). Those in attendance at the First Council accepted this and it has not changed in our modern day.

What is quite intriguing is that it would appear as if Theravadins have taken this proposal and decision of Mahakassapa over the statement of the Buddha himself. As Bhikkhu Bodhi argues, the Vinaya cannot be read in a fixed manner as either unconditionally permitting or forbidding revival of the bhikkhuni sangha. It yields these conclusions only as a result of the interpretation, which depends heavily and reflects on the attitudes of the interpreters and their framework of assumptions (Bodhi 2012: 3). Though Bodhi has argued convincingly that this is a case of the Burmese

\footnotetext{
${ }^{7}$ Freedman's (1977) dissertation, entitled, "The Characterization of Ananda in the Pali Canon of the Theravada: A Hagiographic Study,” discusses the willingness to both praise and denigrate Ananda. This ambivalent treatment of one of the Buddha's most important disciples can take place often within a single text and is reminiscent of the way women are presented in the Canon. It is curious that the very disciple of the Buddha who argued for their inclusion in the sangha should be historically remembered in a way that is similar to the way women are remembered.

${ }^{8}$ There is doubt from a large portion of modern scholars on the historicity of the First Council or the Council of Rajagaha, but for the Burmese, it is an important narrative in Buddhist history and taken more or less as fact (Prebish 1974: 245-256).
} 
sangha (or any sangha which disallows the revival or reinstatement of a bhikkhuni lineage) taking Mahakassapa's decision over the otherwise known rules of the Buddha, I cannot fully support his argument without coming to terms with how largely it supports my own. I am attempting to articulate in this thesis that the disallowing of Burmese thila-shins to be fully ordained is a decision that involves much more than Buddhism because those in power (bhikkhus) are manipulating the text to serve their own patriarchal agenda. Moreover, arguably, one of the biggest cultural conduits for patriarchy in Myanmar is Buddhist literature, perpetuated on social, ideological, and institutional levels. The decision by the council, though, could just as easily be considered a hermeneutical strategy, one that is accepted as what to do when it is not or no longer known what the Buddha meant. That is, because it is impossible to be certain whether particular rules were meant to be major or minor, defaulting to retaining them all seems to be the safest strategy. Though the impetus is still largely on the interpreters, as Bodhi argues, it also forecloses that anyone could know the "authorial intent" of the rules as we have them but must rely on their (our) own "ijtihad" to make a case for how to interpret the rules. Mahakassapa's strategy does seem to be the safest bet while other strategies may require a stronger defense. However, I still find value in Bodhi’s argument, and I believe it carries even more weight in contemporary cultural and social conditions.

A further argument by Bodhi deals with the passage used earlier in this chapter, where Ananda convinces the Buddha to accept an order of women and the Buddha agrees but prophesizes a shortened timeline for Buddhism. There has been 
extensive work and reflection on this prophecy and Bodhi makes an argument that is critical to his understanding of the passage:

[W]e should still note a significant fact about the version that has come down in the Pali canon...namely, that the Buddha is shown making this prophecy only after he has agreed to allow women to go forth. If he truly wanted to prevent women from going forth, he would have made this prophecy while Ananda was still launching his appeal on behalf of the Sakyan women (Bodhi 2005: 108).

Bhikkhu Bodhi brings attention to the simple yet glaring fact that the Buddha waited to make his prophecy after already allowing the bhikkhuni order to be established. Why do bhikkhus, Bodhi asks, want to use this argument to disallow the revival of a bhikkhuni lineage if the Buddha himself did not?

As of today, only Sri Lanka has been successful in reviving a lineage for bhikkhunis, though Thailand is following close behind with influential nuns such as Dhammananda. Burma, interestingly enough, has the largest concentration of nuns but is perhaps the farthest away from attaining full ordination. Though Burma has many influential thila-shins, even thila-shins who are highly respected among the lay community, there are no nuns such as Dhammananda, religious women who are actively arguing for the option of full ordination for women in their country. What is most important and distinctive about her is that she was a well-known Buddhist philosopher at the University of Bangkok before she went to Sri Lanka for her full ordination. Furthermore, she has important friends and supporters in the Parliament, which made it essentially impossible for the Thai Sangha to ignore her and/or her ordination. It should also be stated that though Sri Lanka has been successful in the revival of a lineage for women, Myanmar does not recognize this newly reinstated 
lineage, and thus does not recognize the women who are ordained in it as true bhikkhunis.

It is relevant to mention Revered Saccavida here, a Burmese nun who was ordained as a thila-shin in1986 (Lekshe Tsomo 2014: 44). Saccavida passed the highest Buddhist examinations in Burma, attained the degree of dhammacariya, and received the highest grade among all the thila-shins. In 1988, she travelled to Sri Lanka to pursue graduate studies and subsequently became fully ordained there in 2002. In 2005, her father fell ill and when Saccavida went back to visit him, she was arrested for seventy-six days, charged under section 295 of the Burmese criminal code (which relates to "abusing religion," and to the "desecration of religious buildings and properties”), and was beaten and tortured (Lekshe Tsomo 2014: 44). She was allowed to leave only after being forced to ask forgiveness for her actions along with changing out of her robes and into the robes of a thila-shin. She was then immediately taken to the airport, boarded a plane back to Sri Lanka where she resided for several years and, perhaps most discouraging, disrobed in 2008 due to the trauma she had experienced. What is essential to note is that, before Saccavida made the trip home to Burma, she wrote the religious authorities for "supplication for recognition of my bhikkhuni ordination in Sri Lanka as a fully ordained Myanmar bhikkhuni in the Theravada tradition” (Lekshe Tsomo 2014: 45). She received a letter in response from the Mahanayaka Monastery in Yangon (the official quarters of the highest monks in the country) that read:

We, who know the right view from the wrong view as taught by the blessed one [Buddha], submit herewith: That, Ma Saccavadi, who had received bhikkhuni ordination in Sri Lanka, has now brought forth a wrong view with 
the sole malicious intent to destroy the Buddha dispensation that now flourishes in Myanmar (Lekshe-Tsomo 2014: 45).

Some explain the monastic community’s blatant refusal to recognize efforts for revival in terms of maintaining their status as the sole receivers of the highest donations, meaning that if the lineage is revived, the monks will not be the only members of the monastic community receiving support from the laypeople or the government. Saccavadi says, "monks fear that they will lose their fame; they really fear that they will have to share their donations with the nuns” (Lekshe Tsomo 2014: 45).

More than that, many Burmese laypeople and monastics, as well as several scholars, ${ }^{9}$ see a reinstatement of the order in Burma as a "Westernizing" trend that is likely to be rejected by the Burmese sangha as well as the lay community. It has been argued $^{10}$ that these ideas of freedom and equality may be seen as coming from the West and Western feminism cannot (perhaps even should not) be applied to Buddhist nuns. It should be stated that these are exactly the kind of claims that transnational feminist theory aims to reject. Narayan (1997) criticizes attempts to dismiss ThirdWorld feminist politics (in this case the struggle of the Burmese Buddhist nun) as symptoms of "Westernization.” Such charges, she argues, are connected to the ways that local elites contrast "Western culture" with their specific Third-World "cultures" based on essentialisms that were constructed in colonial times. She thus draws attention to the problematic and ideological nature of these characterizations of “culture” (Narayan 1997: ix). Furthermore, I (along with Narayan) would argue that if

\footnotetext{
${ }^{9}$ Kawanami (2013) and Lekshe-Tsomo (2014).

${ }^{10}$ By prominent monastic teachers in Myanmar such as Ashin Wirathu (New Masoeyein Monastery in Mandalay) to scholars familiar with the standing of Burmese Buddhist nuns such as Kawanami (2013).
} 
there seems to be a considerable resemblance between issues addressed by Western feminists and those addressed by Third-World feminists, it is a result not of faddish mimicry but of the fact that women's inequality is found in many "Western" and “non-Western” cultural contexts. Narayan uses specific examples to draw attention to the seemingly selective and self-serving ways in which particular social changes concerning gender roles in Third-World contexts are painted as "Westernization," while other changes are regarded as consistent with "preserving culture." She begs critical attention be given to the agendas that may be served by the deployment of these terms. In other words, we should be critical toward the political uses to which culture can be put, even if we can recognize meaning-making practices that deal with identity within them.

While these "westernizing" claims should be kept in mind, especially when trying to distance oneself from orientalist representation, there are still thila-shins who wish to seek full ordination because it gives them greater possibilities for development (Lekshe Tsomo 2014: 46). When using the term development here, I am referring to further growth in their own spirituality as well as their education (both spiritual and secular), both of which are real concerns for thila-shins that are not being addressed due to their ordination status. They are facing great difficulty in reaching this kind of progress, and the obstacles do not seem to be their identity or a confinement in their tradition, but rather a direct opposition from the male monastic community that is supported by the current military government. Regardless, Kawanami states that if there is a movement for revival in Burma, "it is unforeseeable that the Buddhist nuns themselves would be particularly instrumental” in this 
restoration (Kawanami 2013: 211). This passage is important in light of what I just discussed because it can be initially unclear. One could read the passage as if Kawanami is insinuating that thila-shins have no will or desire to push for full ordination though I do not think this is accurate. I interpret her passage as meaning that they would be unlikely to be responsible for any changes made because they have little to no authority where monastic affairs are concerned. This, coupled with the fact that very few of them receive or are able to pursue advanced education place them in a position where it would be difficult to initiate change in their communities.

Part of this aggressive relegation from the male community may be due to cultural ideas about the feminine and female sexuality that are deeply rooted in the intellectual thought of Myanmar and, perhaps more importantly, within Theravada Buddhist texts. During my fieldwork, many were proud to answer when I asked them about the status of women in Burma, happy to talk about the progressive rights women have always enjoyed throughout the history of the country. The American anthropologist Melford Spiro takes it one step further, saying "Burmese women probably occupy a higher social status than any other women in Asia... Until the dramatic changes in the status of women in the West in the past fifty years, Burmese women enjoyed a degree of economic, legal, and social equality that arguably was unsurpassable either in Asia, or in Europe and North America” (Spiro 1971: 39). Women in Myanmar have enjoyed a kind of egalitarianism in secular life, but it is an equality that has and does not cross over into the spiritual realm. This view of women in Burma as having a superior status to women in other countries is at odds with the idea that women are spiritually inferior to men. 
How to reconcile this tension? When visiting the religious sites in Burma, one will see various signs in temples, pagodas, and sacred spaces that read "No women beyond this point.” It is not uncommon as a woman to be banned from sacred areas. The contradictory lens through which women are seen mirrors the way women are presented in the Theravada texts. There are more than a few contradictions expressed about women in the texts of the Theravada tradition. More specifically, these confusing remarks are usually about the "nature” (itthibhava) of women, which asserts that women are “weak in wisdom,” “uncontrollable,” (in the Anguttaranikaya) and “envious” (Collett 2014: 61). On the other hand, women are also regarded as “wise and virtuous," (in the Samyutta-nikaya) and sometimes there can be confusion over whether male or female nature is of any importance at all. The first example, from the Anguttara-nikaya, is in reference to a passage in which our friend Ananda asks the Buddha why women do not sit on courts of justice with men, embark on business, or reach the essence of any deed. The Buddha responds to him by listing numerous negative characteristics of women such as that they are weak in wisdom and greedy. In the second example, from the Samyutta-nikaya, the Buddha is talking to a king when he hears that his wife has given birth to a baby girl. The king is initially disappointed by this news until the Buddha tells him that women, too, can be wise and virtuous. In addition, on this side of the coin we have the Therigatha, where many verses include proclamations that suggest the nuns (to whom we attribute these verses) had attained liberation or an Awakening. The well-known verse of Soma ventures to ask whether female or male nature is relevant at all to one following the path. Furthermore, we have the Mahavacchagotta in which the Buddha states that he 
had far more than 500 arahant nuns and far more than 500 laywomen followers who had become non-returners (Collett 2014: 71).

What is important to remember though, is not what the texts say, but which texts are being read in Myanmar. The Pali Canon is a very large collection, and different traditions place emphasis on different sections of this collection. During my fieldwork in Myanmar, I only spoke with one nun who had read the Therigatha, a clear indication that the Therigatha and perhaps even texts like it are not popular among Burmese Buddhists. The Dhammapada, on the other hand, was a text I encountered often. Even some of the extremely poor nuns I came into contact with had a copy of this text. The Dhammapada depicts women as highly seducing and dangerous (to monks and their spiritual path) but there are also depictions of spiritually accomplished women (lay and monastic). Female sexuality as a whole in Buddhism can be ascertained, from examining the texts and rules ascribed to female mendicants, as passive and responsive (to male sexuality). There are fewer instances of women actively seeking out sex than there are of women responding to the sexual behavior of others (Collett 2014: 65). Male sexuality, on the contrary, is depicted as potent, aggressive and proactive. Yet women are burdened with the brunt of male sexuality.

\section{Conclusion}

In trying to examine a comprehensive history of the Theravada bhikkhuni lineage, many questions remain but some clarity can be found from what is known. The need to reinterpret the Buddhist texts in order to discern exactly how best to go about reinstating a bhikkhuni lineage cannot be overstated. In gaining the context for where 
bhikkhunis stand now, it seems we must not ask what the Buddha wanted then, but what he would have wanted now in the twenty-first century. As Theravada history clearly shows us, bhikkhunis are an integral part of the sangha and have been for centuries. Women under primitive Buddhism all the way into women under modern Buddhism have found ways to exist within the confines of a sometimes-exclusionary tradition. Today is no different. The religious authorities in Myanmar-Burma only have a matter of time before they have to contend with the imminent efforts for revival. Whether these reinstatement movements happen immediately, or with time, it is clear that women in Buddhism are not disappearing, even if part of their history has. 


\section{CHAPTER 2}

\section{Religious Mendicants in Myanmar-Burma: Comparing and Contrasting the Lives of Buddhist nuns (Thila-shins) and Monks}

"You are powerful because you know monks.” Candasiri ${ }^{11}$

\section{Introduction}

Although women and men share something close to equal opportunity in the secular realm, there are clear and distinct differences between the socioeconomic status of religious men and religious women in Myanmar-Burma. The country claims to be one that is inherently Buddhist; several censuses have reported that over 90 percent of the country identifies with this tradition. Yet only half of the population's Buddhist spirituality is economically and socially valued by the state and society. This chapter will explore the socioeconomic status of nuns or thila-shins in Burmese society as compared to the socioeconomic status of monks (bhikkhus). I will be looking specifically at how gender and sexuality can affect society's perception of a Buddhist in Myanmar, along with how these perceptions bleed into the everyday lives of Buddhist women. Ordination status can often affect the societal status of religious women as I will show. By first examining political and governmental policies relating to the monastic community in Myanmar and then comparing and contrasting how thila-shins and bhikkhus live using research collected during interviews with monks and nuns from fieldwork in Myanmar during the summer of 2015, I will show that traditional ideas about gender and sexuality hinder the spiritual pursuits of Burmese Buddhist women by confining them to spaces that do not encourage spiritual growth.

\footnotetext{
${ }^{11}$ Interview by author. Mandalay. June 2015.
} 
I argue that these women are not passive victims of a male patriarchy but rather they are actors with agency in their own space, striving for their own specific goals. In addition to this, I demonstrate that there are aspects of female renunciation that cannot be understood by comparing and contrasting them with the ideas of male renunciation.

\section{Religious Governmental Policies}

In comparing and contrasting the lives of monastic women and men in Myanmar, it is interesting to note how they must follow similar governmental rules and regulations despite the ambiguous status of thila-shins who are neither fully ordained nuns nor merely lay practitioners. If we were to draw from textual representations, ${ }^{12}$ the contemporary status of monastic women in Myanmar is more than difficult to define. Their exclusion from the sangha is clearer than their inclusion and this should place them outside the governmentally imposed laws that monastic community or sangha members follow. This is not the case, though, as they must abide by most, if not all, of the same political policies as their male counterparts. In the 1980’s, some thirty years after Myanmar gained its independence from British colonial rule, Buddhism and its practices began to be administered by their own branch within the Burmese government. The Department of Religious Affairs of the Religious Ministry (the name of this branch) and the policies enacted by it help us to see how nuns are understood and accepted in their social and political contexts. Exploring the state’s

\footnotetext{
${ }^{12}$ I am referring here to the Buddhist classification system, which includes laymen, laywomen, nuns, and monks. The contemporary status is connected to this textual representation because thila-shins observe certain traditions reserved for the laywoman and others solely reserved for the woman who is in the sangha.
} 
religious policies, along with any legal provisions that safeguard their religious activities, aids in determining the context in which thila-shins and monks operate.

The government of Myanmar has long since recognized the political value of the vehicle that is Buddhism, not only for social and moral order, but also to win the support of the people. By promoting sasana, or the dispensation of the Buddha and his teachings, the government solidified its legitimacy in the minds of the Burmese people (Kawanami 2013: 117). Subsequently, though, this meant that the tradition of Buddhism was perceived as being above the law. As a dispensation, it is the very order of the world itself. Thinking that this notion, once spread, would perhaps bring problems for the Burmese government, politics had to play an active role within the monastic community and state control was quickly imposed. A centralized, national monastic organization quickly began to take hold as monastic governance was brought under regional administration, a state imposition that is still effective today. In other words, the idea of "separation of church and state" is a foreign one in Myanmar-Burma. One of the central aims of the state's control over Buddhism was to implement policies that would force monastics to distance themselves from the political scene, such as disallowing any sasana promoting person who was part of the sangha to vote in any kind of political election.

A gathering of all Buddhist sects took place in May 1980 with the purpose of reorganizing and "purifying" the monastic community. Nine separate sects of Buddhist monks came out of this congregation and Buddhist nuns came to be affiliated (at least on paper) with the largest Thudhamma sect, which encompasses roughly 90 percent of the total monastic community (Tin Maung Maung Than 1993: 
12-13). This congregation not only quieted the government and general publics' concern that there was a "lowering of monastic standards" which was leading to social instability, but it also provided a space for thila-shins to be included as well as bookmarking the start of a new age for the relationship between the state and the sangha. To be clear, there were no fully ordained nuns before or after this gathering, but rather an organization of the existing religious community. It was fortunate that the thila-shins came to be associated with the Thudhamma sect because it shows recognition by the monks of this assembly that thila-shins were and are religious mendicants.

The government began to exercise more direct control over monastic affairs after this congregation (Kawanami 2013: 111). During the creation of this monastic hierarchy, the National Committee of Supreme Sangha Council was established, which was made up of forty-seven senior monks who were appointed by the government. In other words, the ruling military regime handpicked the society's religious leaders whom they wanted to control monastic affairs. This council became the highest and most prestigious decision-making entity for the sangha; any and all issues regarding monastic affairs, still today, must go through the National Committee. Thila-shins are not, nor have they ever been, part of this Committee; yet all issues monastic women face (should they not be solved by thila-shins themselves) must work their way up to this Committee of monks. The interesting aspect of this situation is not that there is a patriarchal structure in place which ensures that a committee made up solely of men (bhikkhus), appointed by men, heads an organization consisting of both men and women (this phenomenon is not unique to 
Myanmar). The interesting part is that the Burmese government decides (based on convenience, it seems) when thila-shins are part of the sangha and when they are not. For example, when determining who is eligible to be part of the National Committee of Supreme Sangha Council (determining who should take part in the decision making process of Burmese Buddhism), thila-shins are barred from being considered because they are not full members of the monastic community. When determining who can or cannot vote in political elections, however, thila-shins are considered as full members of the monastic community. Their right to vote (and thus possibly to exercise political influence) is forfeited. The liminality and fluidity of their position is clearly demonstrated in these separate examples and is one of the biggest differences between the socioeconomic status of a monk and nun. The monks have the privilege of an unambiguous status where the sangha is concerned; they are always, in every situation, considered to be members. The status of a thila-shin, in contrast, is flexible and possesses the ability to shift. It is ambiguous not just because of what the histories of Buddhism and traditional textual representations of women in Buddhism tell us but also because state organization makes it so.

The organizational chart below, Figure 2, may be helpful in understanding the current position of thila-shins in relation to monks as well as clarifying the contemporary structure of the monastic community (Kawanami 2013: 114). I included this chart for two reasons. The first is to visually demonstrate the ostracism of the nuns. In stark contrast to monks, whose activities, affairs, and interests are discussed by their official elects at the national and regional levels, nuns are represented solely on the two lower levels (state and township division) and they have 
no representation above these levels. Moreover, they must report to the monks who hold positions above them (technically all monks). The second reason for the inclusion of the chart is to make clear the hierarchy a nun must work through in order to have her voice be heard. Though independent in principle, nuns perform their religious duties very much in compliance with the rules and regulations imposed upon them by senior monks who are part of the regional and national tiers.

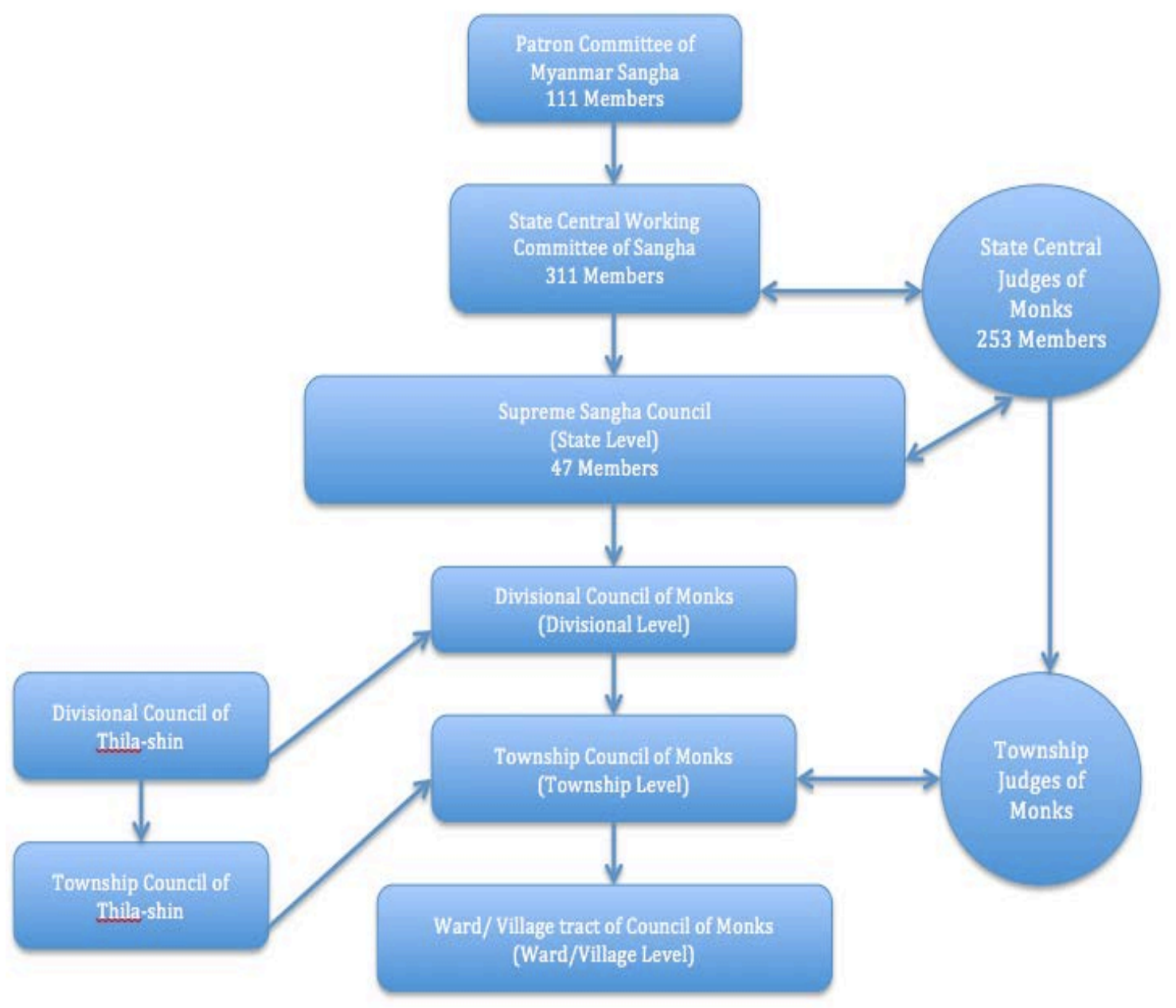

Figure 2. Organization of the Burmese Sangha

If a nun should wish to bring an issue to the national level, she must entrust this issue to a monk in order for it to be heard by the higher ranks of the monastic organization. 
This can often result in the marginalization of women's issues and their education. To demonstrate this, see Figure 3 below, which depicts the place of thila-shins in many classrooms. Furthermore, to complicate the situation, only those nuns who are operating a nunnery school may be nominated or elected into the Council of Thilashins at the township level which, according to Kawanami (2013), is the most active body concerning the day-to-day affairs of nuns. This would not be a problem, but many nunneries are not active schooling centers, or at least not considered schooling centers according to the state's stipulations, for a number of reasons but mostly due to lack of resources. Many nuns, as pictured below in Figure 3, will travel to a nearby monastery to attend classes if the monastery permits it, but are usually seated in the very back of the room and rarely speak. Any independent nunnery not functioning as a school, or any group of nuns who live in monasteries under the supervision of monks ${ }^{13}$, have no thila-shin among them who is eligible to be representative of their needs.

This results in a kind of respect for any nun who manages to be in close connection to a monk, especially a monk who holds a high rank. This is demonstrated in the quotation by Candasiri used at the beginning of this chapter, who believes that nuns hold more power due to their associations with monks, associations that are a rarity for most thila-shins. Candasiri, of the Chan State, has been a thila-shin for twenty-four years and now resides at Thila-Nyunt nunnery in the city of Sagaing, the site where I conducted the majority of my interviews. Here, I would like to shift to

\footnotetext{
${ }^{13}$ It may be important to note here that monks, and not the government, appoints the head of monasteries. Being the head monk of a monastery usually means exercising a great deal of power depending on the prominence of the monastery. In any case, though, running a monastery is respected much more than running a nunnery.
} 
more of an ethnographic mode in order to discuss Thila-Nyunt and some of the nuns who reside there. I will return to an analysis of policies after, but feel it is necessary to briefly delve into my experience in the field.

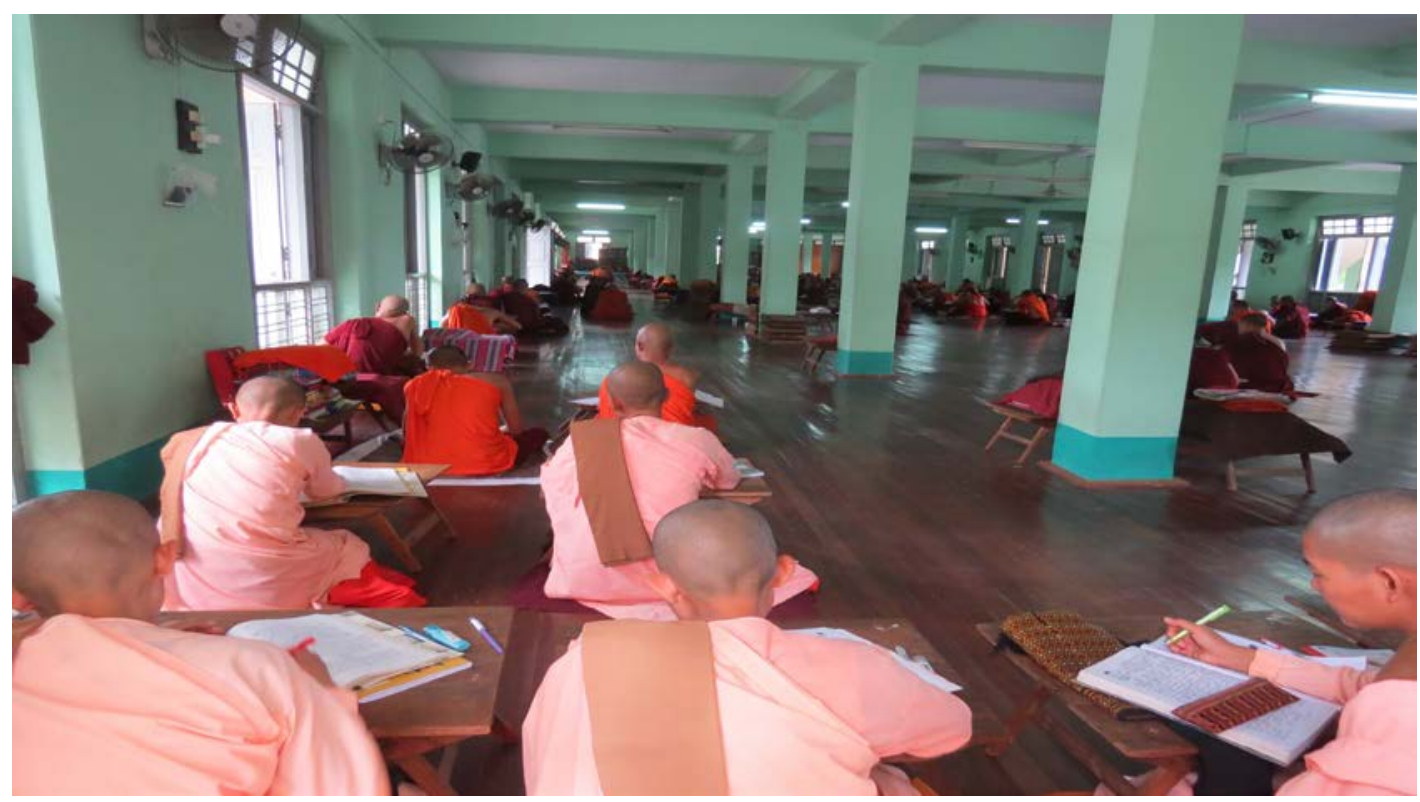

Figure 3. Nuns sitting in the very back of the classroom at New Masoeyein Monastery in Mandalay

\section{Thila-Nyunt Nunnery}

Thila-Nyunt is not a registered nunnery school and was one of the poorer nunneries I encountered, but seemed to be an accurate representation of the way thila-shins live on average. I saw few nunneries in better condition, few in worse, and many that were similar. Around 90 nuns live in this small community, many of them in individual huts or "hostels," with the younger nuns (ages four to twelve) sleeping together in a larger hut. When Candasiri took me to Thila-Nyunt nunnery for the first time, where I would later live as a thila-shin myself, I was fascinated. This was where I began to see firsthand the radical difference of living quarters thila-shins experience compared to that of monks and novices. Much like the monasteries I visited, Thila-Nyunt 
functions almost as a tiny village, but with dirt roads leading to the doorstep of each individual hostel, a common area where the younger nuns eat their meals, and a small area of land reserved for restrooms (squat toilets). There is a pagoda that sits at the top of a hill where daily mediation takes place and it is worth mentioning that this structure is by far the nicest one in the nunnery. There is a kitchen, but many nuns who live in their own hostels have their own ways of cooking food in their own tiny spaces. The younger nuns (ages four to nine or ten) sleep together in one large hut, which is shown below in Figure 4, while the older nuns share spaces with one or two others. The eldest and most experienced or revered nuns live alone. The difference in the caliber of buildings was perhaps more apparent than anything else, barring the lack of paved roads that most monasteries enjoy. Every structure, aside from the pagoda, was a roughly built shack. They were all wooden cabin-looking things sitting on stilts with roofs prone to leaking.

As Candasiri walked me around the nunnery for the first time, initially showing me the pagoda and then her hostel and the common areas, I relished in how the nunnery seemed so alive. There were thila-shins milling about in half their robes, hanging pink and orange cloth on clotheslines to dry, nuns walking with towels slung over their shoulder on their way to take a shower, nuns sitting on the tiny porches of their hostels in silent meditation, and even nuns laughing and smiling at one another in conversation. These were the women I had come to study but had scarcely read about. 


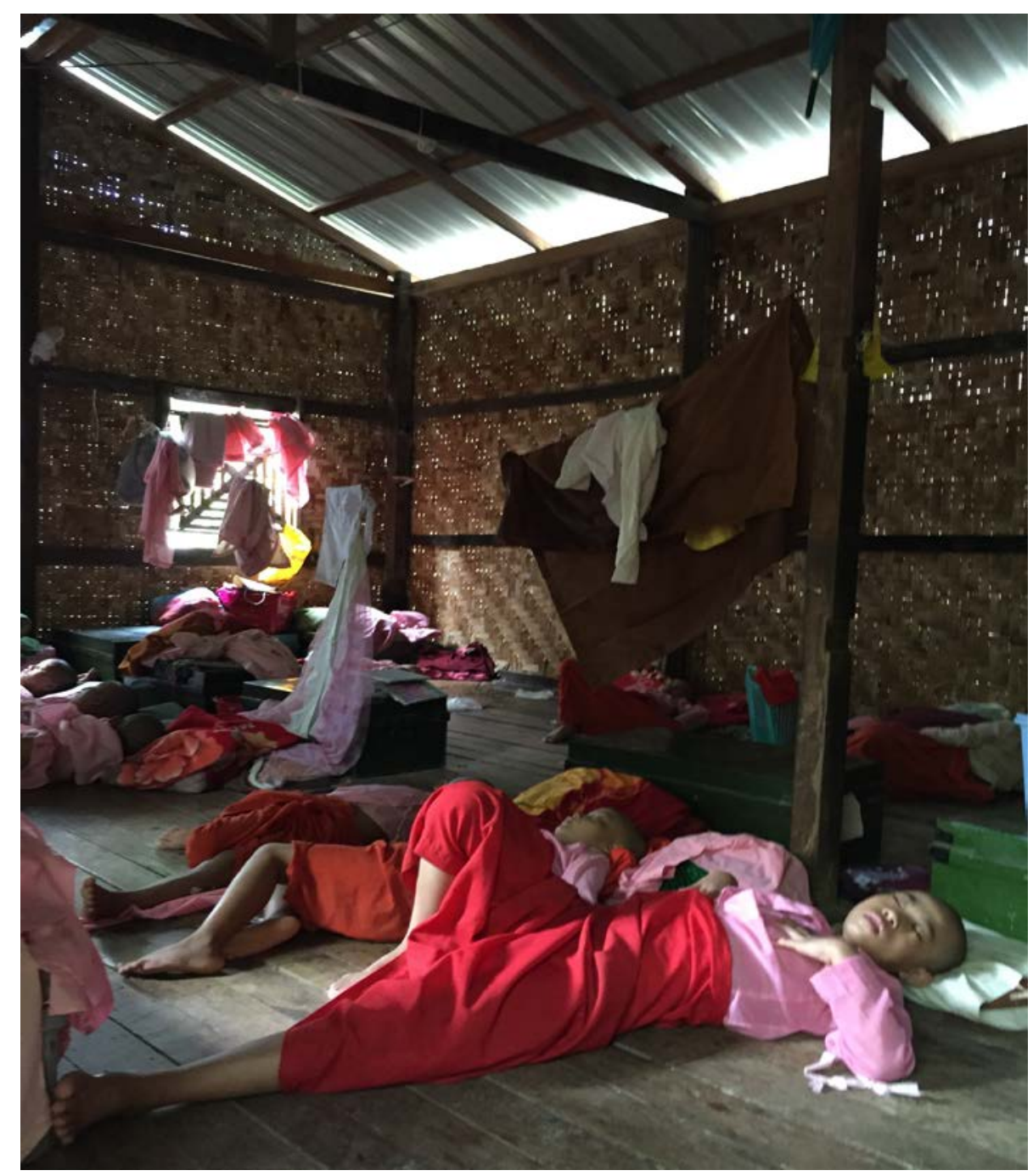

Figure 4. Sleeping area/hostel for the younger nuns of Thila-Nyunt

After the first tour of the nunnery, Candasiri brought me back to where the kitchen area was, offered me a seat, and some juice and bread. This is when I first met Sandayee, Komala, Sitala, Pannadee and the Head nun of Thila-Nyunt, Daw Vannacari. The Head nun of Thila-Nyunt is Sandayee's great aunt while Komala, Sitala, and Pannadee are her aunts. The Head nun's sister, Sandayee’s grandmother and the mother of her aunts, lives at the nunnery with her husband though neither of them are monastics (obviously, as they are married). This familial organizational 
structure is rare for a nunnery, most of them are not run and taken care of by families. Sandayee's mother, the only of her sisters who did not become a thila-shin, works on a farm several hours away. Around once a month Sandayee's grandmother and grandfather will drive to the farm to collect crops to bring back to the nunnery as food for the nuns. Her grandfather was the only man, including monastics and laymen, who lived at the nunnery and one of the very few men who had ever set foot inside the nunnery. I arranged several times for Panna Jota (whose hostel, the middle building, is shown below in Figure 5 while Candasiri's is depicted in Figure 6) and Candavara to come to the nunnery and was shocked to learn that before this, no monk had ever been to Thila-Nyunt. This is indicative of the way thila-shins and monks interact in Myanmar: most of the time, they simply do not.

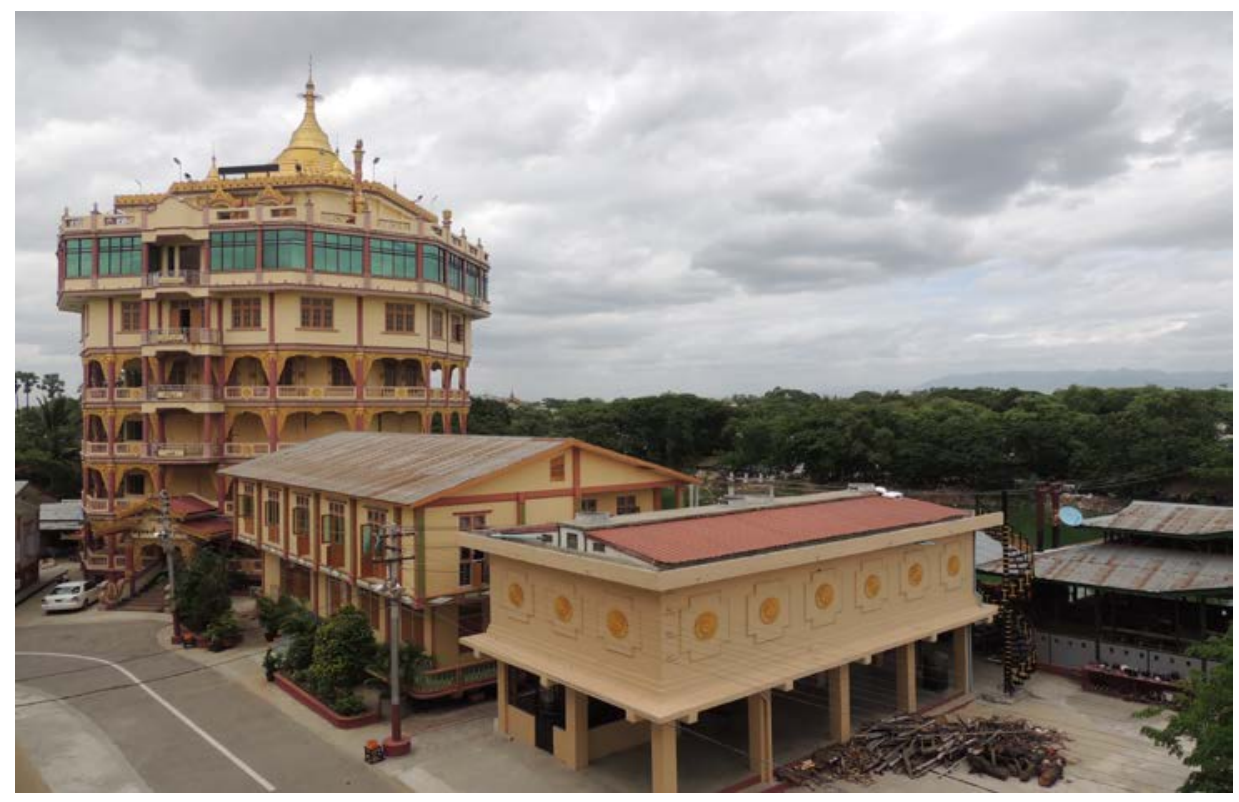

Figure 5. Partial image of New Masoeyein Monastery in Mandalay. Panna Jota's hostel is the middle building. 


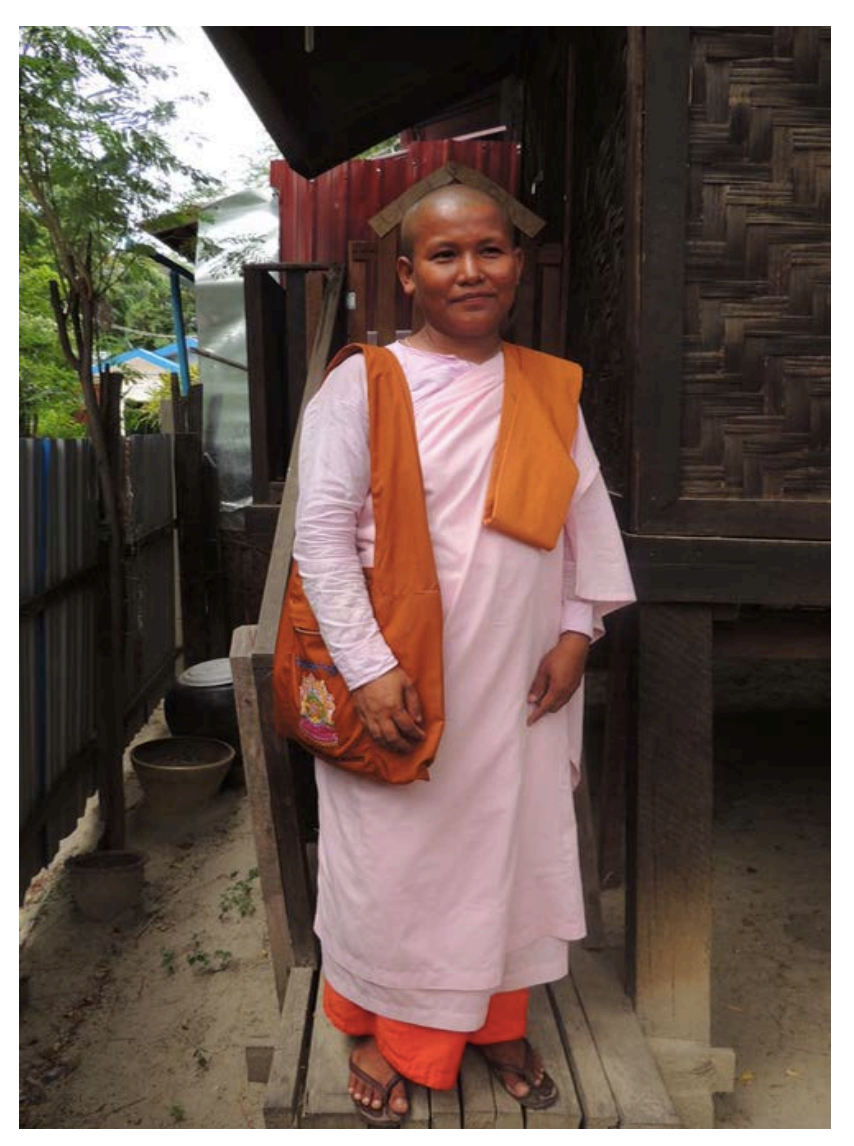

Figure 6. Candasiri in front of her hostel, Sagaing, Myanmar

While nuns view fraternizing with monks as a power that has the potential to be influential, monks (not surprisingly) do not feel the same about (public) relationships with nuns. One of my main informants who was a monk, Candavara, a teacher at the International Buddhist Academy in Sagaing, said, "I can sit together and talk together [with thila-shins] but I don't want to go outside with them because it is uncomfortable” (Candavara 2015). When pressed on the matter, he could not quite explain what he meant by the word "uncomfortable."

\section{Legal Status of a Monastic in Myanmar}

When a man renounces in Myanmar and decides to fully devote his life to Buddhism, his entire legal status is altered. The decision can even be referred to as a 
"civil death," as there is a cessation of ties to family and even a divestment of property. One is given a new name and the event is seen also as a "second birth," because the one who renounces is understood as becoming a completely new being. Becoming a monk in Myanmar means bringing an end to ones entire secular identity (hence the reverence and respect for religious persons willfully choosing to enter the sangha). Once he is ordained, he ceases to follow the law and falls directly under the jurisdiction of the Vinaya, or moral code of conduct for Buddhist monastics, which specifies that he must renounce all legal rights and any inheritance. (Kawanami 2013: 119).

By contrast, a woman's legal status is largely unaffected by her decision to become a thila-shin. Though the decision to renounce is for all intensive purposes the same (women, too, decide to fully devote their lives to Buddhism and give up all belongings along with their name), women continue to be bound by normative secular law in the same manner as a laywoman because of the full ordination issue. They continue to be able inherit estates and even retain the right to keep property (Kawanami 1997: 319). Both men and women require a benefactor(s) in order to renounce; upon receiving their monastic robes they will also receive the designated shoes for monastics along with a toothbrush and other essentials that said benefactor(s) will provide. So while the renunciations are essentially the same, a newly renounced thila-shin is in a kind of predicament due to her gender: she has chosen to sever her material ties and become an "other-worldly" individual but still possesses social obligations and "worldly" responsibilities. This affects the general perception of female renunciation, which is interestingly seen as less of a sacrifice 
than male renunciation. I say interestingly (perhaps ironically) because typically and as I saw during my fieldwork, thila-shins live in a much deeper poverty than monks. The stigma ${ }^{14}$ surrounding female renunciation perpetuates this poverty for thila-shins, greatly affecting the amount and kind of donations they receive (which will be discussed later).

If thila-shins were able to become fully ordained, it is somewhat safe to assume that they would have a larger role in the decision-making process of monastic affairs and that they would be integrated into the committees that sit at the national and regional levels. Traditional Buddhist texts show us that monks and nuns historically worked together in running the sangha. Regardless of the subordinate status awarded to nuns in earlier times, the Buddha assented that women could create their own lineage and so were included in the inner-workings of the monastic community. Scholars (Bonnet-Acosta, Lekshe Tsomo), as noted above, have mentioned the clear link between full ordination and socioeconomic status for nuns in Buddhist countries. As Lekshe Tsomo (1999: 9) explains,

The status of nuns within the Buddhist traditions seems to correlate with ordination status. Coincidentally or not, where full ordination as a bhikkhuni is available, the nuns' level of education and status within the society also tends to be high. Where novice ordination as a sramanerika is available to nuns, women are recognized as members of the sangha even though they are not afforded equal treatment. Without access to full ordination or even novice ordination, women in such Theravada countries are in secondary and often subservient roles, relative to monks, in the religious sphere.

Making full ordination possible for women in Myanmar would drastically improve their quality of life. Unfortunately, the Supreme Sangha Council made an official statement in 2004 that reaffirmed their position, which states that there is no ordained

\footnotetext{
${ }^{14}$ Stigma here referring not only to the lack of full ordination but also to the social attitudes surrounding the idea of a woman renouncing in Myanmar: that of it being trivialized, not as prestigious, not as worthy of reverence.
} 
bhikkhuni lineage in Myanmar (Kawanami 2013: 109). Despite this conclusion, there are still around 50,000 (in 2013) thila-shins registered with the Department of Religious Affairs of the Religious Ministry and this number is steadily increasing.

Government officials refer to monks and male novices (those in training to become monks) as thathana win or those who are "inside" the sasana both in casual conversation and when speaking about them. Thila-shins, on the other hand, are referred to as thathana anwee, or, those who are "related to" the sasana (Kawanami 2013: 120). They can also be referred to as bhikkhuni anwe, which implies that they are "descendants" of past bhikkhunis. Any and all of these signifying terms convey a connection of thila-shins to the monastic order, but do not solidify their full and complete membership. At worst they are seen as being affiliates of the sangha and at best as "relatives" or "descendants" of the once active bhikkhuni lineage. Kawanami (2013) reminds us what must be noted: these same reference terms are extended to include hermits, lay devotees, meditators, religious trustees and any and all who engage in full time work toward the dissemination of the sasana. One would assume that the ambiguous position of a thila-shin would discourage women from becoming one, and yet, female renunciation in Myanmar is on the rise. The robust presence of thila-shins despite a bhikkhuni lineage is (one) reason (among many) to explore their social, political, and economic role in their communities.

Here, it may be useful to note that when speaking to many of my informants who were thila-shins, they did not express any desire to be elected into the Council of Thila-shins at the township level (or a council at any level for that matter), nor did they express any overt desire to have the same socioeconomic status as a monk. 
Though some thila-shins expressed a desire to be fully ordained, not all of them did, which is extremely important to understand for the purposes of this research. Before completing my fieldwork, I (perhaps blindly) agreed with Kawanami’s argument that the reinstatement of a bhikkhuni lineage would most likely be rejected due to many seeing it as a Westernizing trend, one that, if carried out, would not have thila-shins as instrumental players anyway (Kawanami 1997: 211). Elizabeth Nissan (1984) is another scholar who sees the movement to restore the bhikkhuni lineage as an imitation of Western feminisms that have gender equality cemented as their main goal ${ }^{15}$. After completing my fieldwork, I am hesitant to accept Nissan and Kawanami. The Western feminist movement does not seem to be applicable to the struggles of the thila-shins.

Narayan (1997) focuses mainly on the Indian context but I believe her insights to be relevant to the task at hand. It seems that many social and/or political movements being conducted by women in developing countries can be labeled as unproductive due to many viewing them as Western reproductions of feminism. Narayan suggests that these movements are not replicas or reproductions, but rather they are unique, local responses to local issues and cultures. In her words,

Those in Third-World contexts who dismiss the politics of feminists in their midst as a symptom of "Westernization" not only fail to consider how these feminists' experiences within their Third-World contexts have shaped and informed their politics, but also fail to acknowledge that their feminist analyses are results of political organizing and political mobilization, initiated and sustained by women within these Third-World contexts (Narayan 1997: 14).

It seems to me that living in global modernity makes it impossible for us to live without influence from the West and Narayan is recognizing that while offering an

\footnotetext{
${ }^{15}$ I also take issue with this point, as I would argue that not all Western feminists have gender equality as their main goal.
} 
alternative perspective to the issue. Third World women are subject to many of the same globalizing influences as Western women: they have experienced the movement of democracy, they have seen the global legal expansion of concern for human rights, they have been subject to the same economic trends that have pushed many global women into waged work outside the home. They have also experienced the huge expansion of lifespan, the drop in maternal and infant mortality, and the lowered fertility rates that resulted from them. All of these things forever changed the roles of women in society. The only way to justify the marginalization of women is to naturalize marginalization and make it tradition, which has been happening in Myanmar, as the ideas of egalitarianism and inclusion are simultaneously being cast as "foreign" and "modern” inventions. Are marginalizers and liberals not both affected by the West as well as their own traditions? It seems unavoidable. I think that women involved in alternative feminist movements need an alternative vision of the world to help them imagine a reality that looks different from their own. Western feminism (and democracy among other things) provides that, if only in part.

It was difficult for me, at first, to accept that thila-shins were not concerned with the same things I was concerned with. I began my fieldwork assuming that an equal status to monks as well as full ordination were obvious desires for every thilashin, probably because it is part of my own desire that thila-shins be fully ordained. This could not have been more inaccurate. Thila-shins may be aware of the gender dynamics that result in their subordination, but may consider them to be personal problems and not a systematic part of the ways in which society scripts gender roles and thus the lives of women. Many of them expressed that their lack of ordination 
affected their aptitude to practice the Buddha's teachings to the best of their ability and this was their biggest concern, not perfect egalitarianism. I feel that Narayan's work puts forth a way of viewing the nuns' situation that does not remove it from its own context (where it belongs). If they were to attain full ordination, it would not be because of a traditionally Western feminist agenda. It would not be one that is concerned with gender equality and freedom, but rather one that involves altering their environment so it is more accepting of their spiritual pursuits.

\section{Female vs. Male Renunciation}

Even though Burmese women have enjoyed certain rights and an elevated status in the secular realm that may not be common in other Asian countries, there is still the generally accepted notion that women are spiritually inferior to men. On top of this, it is said in Myanmar that men are endowed with hpoung, which refers to an innate glory or charisma that only men possess. This hpoung means that men are superior to women in aspects of the intellect and spirit, two things that are intensely significant on the path to enlightenment (Lekshe Tsomo, 2014: 40). Burmese author Mi Mi Khaing explains this by recalling that because the Buddha himself was a male, and because he was able to achieve the highest spiritual goal of enlightenment, only a man can hope to achieve a similar aim (Lekshe Tsomo, 2014: 40). Women, who lack this hpoung, rely on other aspects related to femininity to foster their faith.

Traditional feminine virtues that may be seen as "out of date" or antiquated provide an ethical foundation for nuns to build their faith on. Two male informants referenced Aung Sun Suu Kyi, saying that they "liked what she had done but that she 
should try and be more like Mother Teresa and stay out of politics.” ${ }^{16}$ Saba Mahmood (2005: 6) has alluded to the fact that “Women’s subordination to feminine virtues, such as shyness, modesty, and humility, appears to be the necessary condition for their enhanced public role in religious and political life.” As a clear example of this, we can look to the way thila-shins wear their robes in Myanmar.

Modesty is an extremely important virtue for a thila-shin to possess as Buddhist texts and popular belief portray feminine sexuality as dangerous and something that could cause one to stray from the path toward enlightenment. Due to these ideas about her dangerous feminine sexuality, a thila-shin is constantly working to hide any indication of its existence, typically with passionate dedication to the Buddha's teachings, but most notably in her effort to cover up the curves of her body. Even though Myanmar often exceeds temperatures of 95 degrees, thila-shins wear five different layers of fabric as part of their religious uniform, light pink in color so as to make clear their inferior status to the saffron robes worn by the ordained monks and novices on the path to monkhood. The robes a Buddhist nun wears can easily be viewed as a cultural emblem, one that lies deeply embedded in traditional ideas of a “good” and "pure” femininity. The bottom sarong (orange in color) reaches all the way down to a thila-shin's ankles. The snug, upper bodice, which is long sleeved and fitted to each nun, lies underneath an outer layer that resembles a blouse and reaches down to her feet as well, covering the initial orange layer and the bodice. The ensemble is only made complete with a separate top layer that is draped over the left shoulder, covering all three pieces that were donned before it, and a tannish, brown

\footnotetext{
${ }^{16}$ Names withheld to protect privacy. Interview with author. Mandalay. July 2015.
} 
shawl that is placed over the left chest. The shawl can be looped around the chest or just placed over the left shoulder, but either way it is successful in concealing a thilashins breasts. The resulting effect is that every curve of a woman's body is hidden under the fabric.

All of the separate pieces of a nun's ensemble play a significant role in preserving her purity and projecting an almost "genderless" persona that is void of any sexuality at all, made all the more androgynous with their shaved head. A nun must wear her robes correctly and neatly and can even be reprimanded if she is not clothed accordingly, due to her outward appearance being viewed as a visible expression of her inner virtue (Wijayaratna 1990: 44-45). This perpetuates the normative standards of womanhood in Burmese society and even extends to the lay community. ${ }^{17}$ Effacing their womanhood is a clear attempt to reject their womanhood, building on the idea that womanhood and spirituality are not two things that go together. In writing this thesis, I was consistently confronted with the question that seems to drive many different feminist movements: is gender equality best achieved by stressing the similarities between women and men or the differences between them? In Myanmar, thila-shins are certainly stressing the first, their similarities, while their differences are at worst used against them or at best ignored.

When I asked the nuns I stayed with during my fieldwork to comment on their robes, one in particular responded by saying, "I like my robes because they cover my

\footnotetext{
${ }^{17}$ Though this thesis is not focused on the lay community, it is worth noting that laywomen in Myanmar are also concerned with projecting a kind of purity and virtue through their outward appearance. Even in today's modern age, it is rare to see a woman wearing clothing that reveals her legs or shoulders. Traditionally, the women wear long skirts with short sleeve shirts. This contrasts with laymen, who can be seen walking around publicly without a shirt or with exposed thighs and knees.
} 
body and I do not like my body. My body does not help me meditate, it does not help my mind, it does not help me honor the Buddha.” In my textual research as well as my fieldwork, I have noted that sex or sexuality seems to only be equated with the feminine. This causes some thila-shins to harbor negative feelings toward their own bodies due to the negative sexual stigma imposed on them by their tradition and its ancient texts (and subsequently, their society). If we understand that the enemy in Buddhism is attachment to sex, not to women, then we understand that when a passage with disparaging statements about "women" is encountered, the content simply indicates the sexual (Jung, Hunt, and Balakrishnan 2001: 115). I did not see this same, negative sentiment expressed toward the body by monks, who admittedly, may have neglected to mention these feelings (if they had them at all) on account of our opposite genders. In any case, the ensemble for monks differs greatly from that of a thila-shin. This difference in dress may be helpful in locating the anxieties placed upon the female form in Burmese culture.

Monks are not required to cover all of their skin, though some choose to, especially in unusually low temperatures during the rainy months. Monks must wear just two layers, a lower sarong and an upper layer that drapes over the shoulder and chest, and their full right arm is exposed. Panna Jota, one of my informants who is a teacher at the New Masoeyein Monastery in Mandalay, educated me on why the full right arm is exposed and the robes are draped over the left. "The left arm symbolizes power and the right arm symbolizes wisdom. It is not suitable for a monk to show off power, it should be hidden. Wisdom can be shown.” When I asked why thila-shins must cover both arms, both wisdom and power, Panna Jota responded by simply 
saying, "It is not the same.” Typically, because the above layer is simply draped over the shoulder, the left arm ends up being exposed as well in simple movements of the arm. Sometimes, even a monk's abdomen, ribs, and chest can be exposed if he is to lift his arms over his head (which is perfectly fine, but would be a completely different story if a thila-shin were to do it). Monks exercise a kind of comfort in public (as seen in the picture below) that you will not find in a thila-shin, more than likely due to the lack of anxiety that surrounds their body. Some, but not all, monks choose to wear a fitted bodice under their top draped layer of fabric, which is similar to the fitted bodice that thila-shins wear. The difference lies in it being sleeveless on one side, only covering one shoulder. Monks are able to choose the color of their robes: the dark saffron that resembles a burgundy or a burnt orange—either one is acceptable—and most monks choose by preference. The robes for a monk, considerably less restrictive and modest (demonstrated below in Figure 7), also carry with them a reverence that is not awarded to the pink robes of a thila-shin.

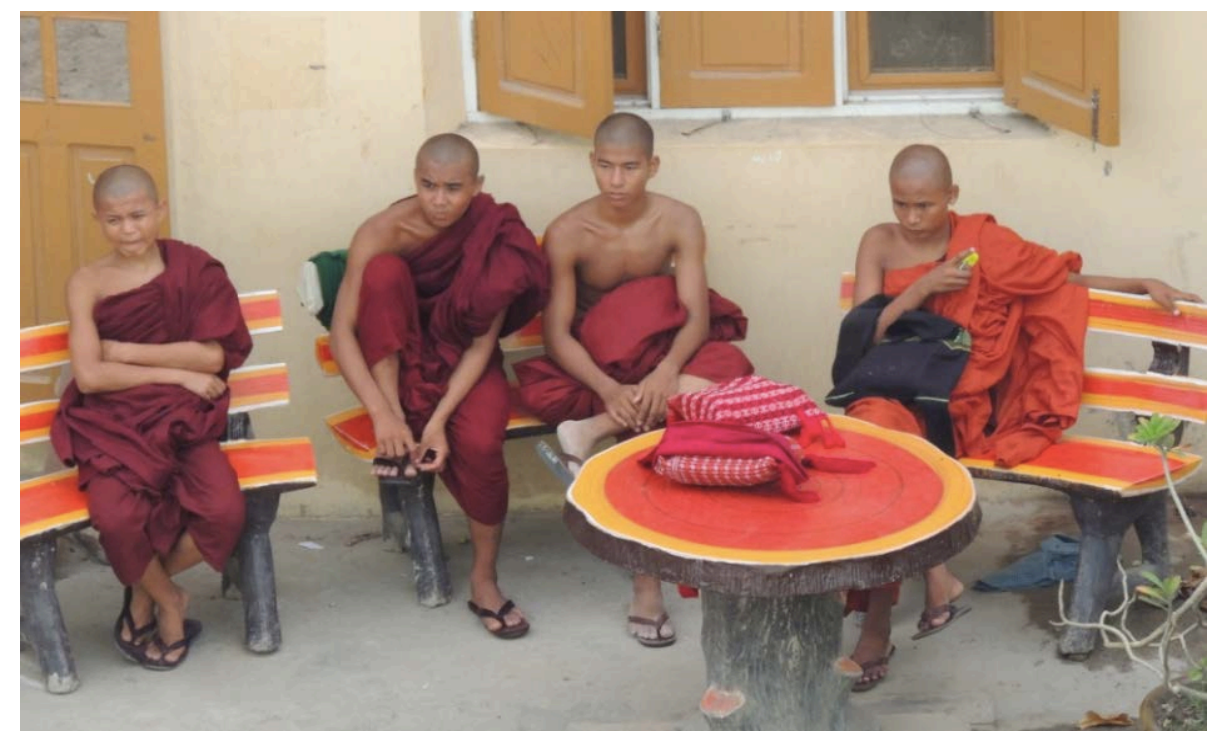

Figure 7. Novices relaxing during a midday break, New Masoeyein Monastery, Mandalay 
Buddhist texts describe the body as a mere "heap of bones covered with flesh and besmeared with blood under the shadow of decay and death," solidifying the Buddhist belief that there is no self, no one to inhabit this physical form (Buddhaghosa 1973: 217). It seems that the body one inhabits while practicing Buddhism should not matter if we adhere to the texts. Yet, we have seen that it does matter. Monks are entitled to their body and the nature of their body in a way that a thila-shin is not. Buddhist literature consistently dictates that bodily restriction is necessary because everything about her becomes sexualized. The code of discipline for bhikkhunis in the Patimokkha gives 311 rules nuns must follow, of which thirtyfive are sex related. Bhikkhus must follow 227 rules, of which fifteen are sex-related (Pruitt 2001: 37). With the discrepancies in these numbers aside, many of the rules establish a hierarchy that has a basis on gender. What one can discern from these rules is that sex is a larger problem or greater obstacle to overcome for bhikkhunis than it is for bhikkhus along with the idea that bhikkhunis are inferior to men due to their gender. Though women are not the authors of these narratives pertaining to female sexuality and competence, it is their burden to bear. When considering this, it is easy to see a resemblance between the way thila-shins are treated within the sangha as well as in society.

Lay practitioners in Myanmar are highly concerned with accruing merit (bun). Acquiring merit can be achieved in a number of different ways, such as through meditation or ethical actions. No matter the means by which it is acquired, it is imperative to all forms of Buddhism. In Myanmar specifically, though, there is a special emphasis placed on acts of giving or dana. Donating or giving to a monastic is 
one of the central ways in which a person might accrue this good merit and subsequently solidify a favorable rebirth. In my fieldwork, I came across many families who would spend birthdays or noteworthy events in the family at a monastery, providing food for all the monks and novices who lived there along with making a large donation to the monastery as a means of celebration. Furthermore, the World Giving Index just released a report that ranks Myanmar as the most charitable country in the world (Cole 2015). While this may be true, the report fails to mention where the majority of these charitable donations go. Many in Myanmar believe it is favorable to donate to a monk over a thila-shin because thila-shins fall "betwixt and between” being a monastic and a layperson. Giving to someone who has a full membership in the sangha will accrue a greater amount of good merit than donating to someone who has an equivocal position in the sangha. This results in an extremely unequal allocation of donations going to monks even though both monks and nuns are dependent on the laity. Furthermore, nuns themselves believe this ideology, and I watched as many of the Thila-Nyunt nuns spent their mornings preparing half of their food for themselves and other nuns, and the other half for monks who collected their morning alms from them. This is shown below in Figure 8, as I have included a photo of Komala Terri of Thila-Nyunt serving young novices food. Effectively, the monks are saying that they are laywomen and nothing more. The reverse circumstance, nuns collecting food from a monastery, is not something I saw during my fieldwork. 
Gathering alms is seen as one most significant symbolic acts and perhaps the most important religious duty of a mendicant in terms of interacting with society.

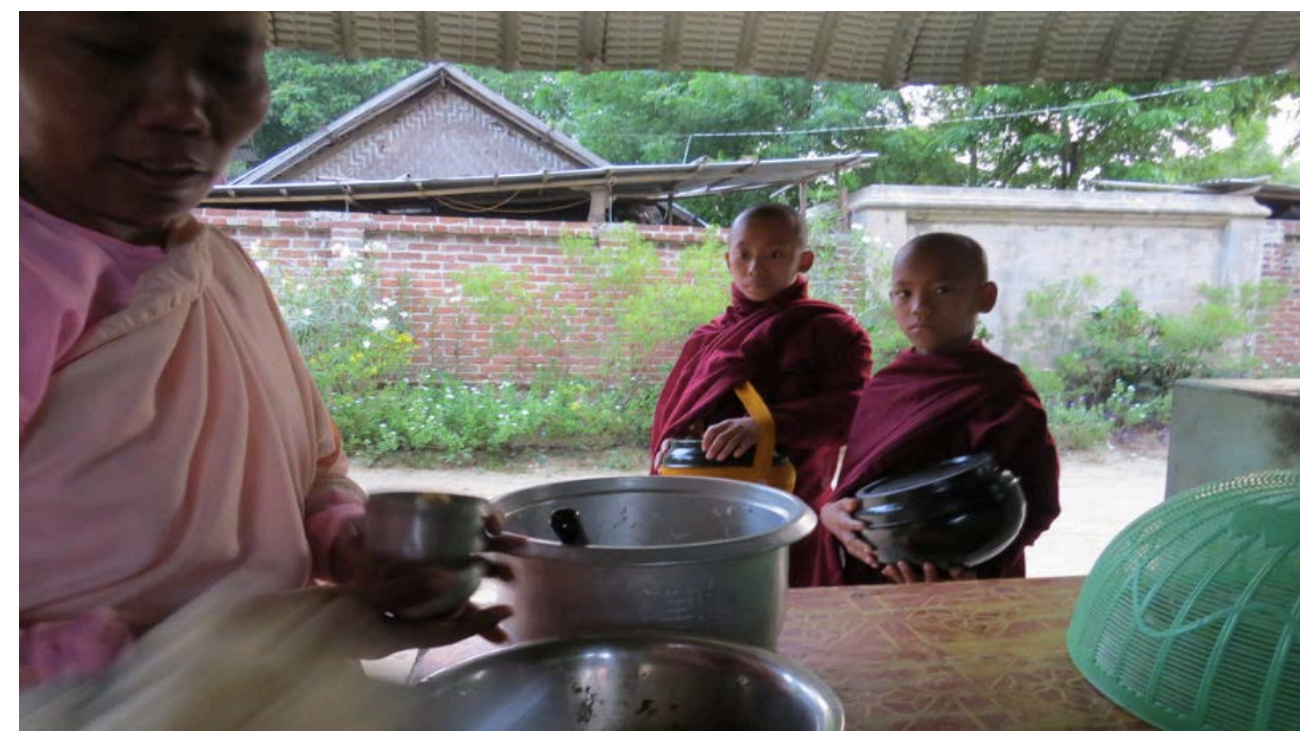

Figure 8. Komala Terri of Thila-Nyunt serving food to novices on their morning alms rounds

Each morning, monks and novices rise before the sun to travel barefoot while carrying dark enamel bowls in order to collect the prepared food that has been waiting for them since dawn. nuns, in stark contrast, travel to collect alms or donations just two to three times a month (or week, depending on the nunnery and how much they need) and the experience is exhausting and frequently humiliating. nuns receive raw rice as opposed to the cooked rice or food that monks receive.

Thila-shins, who must continue to adhere to social norms imposed upon them as mendicants, are still expected to cook for themselves in mendicancy. This differentiation can be detrimental to a nun's self esteem, which is affected by her desire to be a spiritual individual while still having to operate within societal norms that see her as in between the spiritual and material. To maximize the amount of alms they take home, nuns on collection days will call on households and places of work 
alike regardless of whether or not they know those who live and work there. They walk the streets incessantly chanting for donations and at times donors, who may not even know whether they are proper thila-shins or just beggars, will give the raw rice or a small amount of cash in order to fill their fleeting sense of religious duty or even to get rid of those who practice insistent chanting on their doorstep. The whole experience is vastly different from that of a monks. While monks can gloss over the fact that they are dependent on their donations by highlighting the idea that a donation to them means an accumulation of favorable merit, nuns do not have the luxury of displaying such confidence in their alms collecting. Spiro even goes so far as to comment that a monk "will make his daily rounds, not for his own benefit but for the laymen’s” (1971: 411).

By contrast, in recent years, shop and homeowners have taken to leaving a bowl of uncooked rice along with a tiny scooper outside their home with a sign reading "self-service," which completely removes the ritual aspect from the exchange. This lack of personal interaction completely removes the religious significance and expected moral-economic outcome. If there is no face-to-face meeting with those who act as benefactors to the nuns, then there is no opportunity for them to bestow a blessing which is arguably the most important part of the ritual in terms of receiving merit. nuns have taken to chanting their blessings anyway in hopes that the person will accrue the merit sans the face-to-face meeting. Kawanami argues that as the relationship between nuns and urban donors becomes further deprived of human contact, it will become empty of religious value and morph into a kind of "commodity exchange" in which the thila-shins have nothing to offer in 
return (2013: 154). This could be detrimental to the status of a Burmese nun, who would fall into a kind of perpetual dependency. Many junior and senior nuns outwardly expressed to me their dread of alms collecting days. They must leave the nunnery before dawn and do not return until around five p.m. looking sweaty and haggard. If the trend continues in this direction, nuns could lose their already shaky religious status and start to be seen solely as needy beggars instead of the spiritually inclined beings they are.

\section{Conclusion}

Although there are many obstacles Burmese Buddhist nuns must overcome in order to practice their chosen tradition, they are continuing to find ways to do so in environments that do not always see their spirituality as legitimate or appropriate. The post conflict process and democratization that Myanmar is currently undergoing (starting in 2010) could prove to be beneficial to the socioeconomic (and even religious) status of thila-shins, and could even have an effect on the religious standing of all monastic members. It can be a slow process, but as the free flow of information floods into Myanmar in a way that it never has before and details about the outside world become available, traditional Burmese culture will find itself having to identify with modern secular values. It is my own view that much of the issues result from the lack of feminine voices in Buddhist literature. There needs to be a space created within Burmese Buddhism that allows these voices to be heard. The subordination of Buddhist nuns to monks in the socioeconomic and monastic realms seems to be a construct that serves political purposes rather than spiritually enlightening ones. By tracing the historical transformations of the Theravada tradition, contemporary men 
and women can initiate changes to meet their own lived concerns. Women can and should reclaim their (hi)stories, which will enable them to live full lives as Buddhists in whatever way is meaningfully determined by them in relation to their tradition. Buddhism is not inherently sexist but social and cultural norms often are. I have attempted to show how gender and sexuality are very much intertwined with ones social, political, and religious role in Burmese society.

By examining political provisions relating to the monastic community, briefly discussing the issue of full ordination for women in Myanmar, and providing data from interviews collected in Myanmar during research fieldwork I have attempted to show the differences between the socioeconomic status of Buddhist monks and nuns in Myanmar-Burma. Bhikkhus and thila-shins in Myanmar find their self-perception in those things that exist outside of the material; they locate their identity in their role as carriers of the dhamma; and they operate as though their religion is above and outside those things that exist in this world. Both consider themselves the "moral conscience” of the country and both should be treated as such. 


\section{CHAPTER 3}

\section{Ethics and Equality in Burmese Buddhism: Full Ordination for Women}

\section{Introduction}

Having explored the history of the bhikkhuni lineage in the two previous chapters and subsequently their current socioeconomic status in contemporary Burmese culture, in this chapter I would like to examine the attitudes of thila-shins and monks toward a revival of the lineage. Along with this examination, I will also be attempting to make the argument that not supporting a revival or reinstatement could result in the accruement of negative karma according to Buddhist doctrine. When first learning of the standing of thila-shins in Myanmar-Burma, I was somewhat bewildered. The nature of their situation surprised me and is what led me to pursue this research. Before delving deeply into the field of religious studies, I was under the impression that Buddhism was a peaceful, ethical, tolerant religion. Sexism, I thought, did not have a place in a tradition that emphasizes the non-self. The longer I have studied Buddhism, however, the more I have come to the realization that I was prescribing to a colonialist and orientalist representation of it, and one that failed to accurately depict the tradition. The imprecise rendering of Theravada Buddhism in the West poses a narrative of a peaceful, far-away Eastern and exotic tradition that is free from corruption. Most are shocked to hear about any conflict at all, such as sexism or Buddhist violence, existing inside the tradition (despite what we know to be true of corruption and conflict in other religious traditions).

The devaluation of feminine spirituality is an example of this misrepresentation. Though the word “tolerant” was first introduced in 1689 by John 
Locke, centuries after Buddhism was a well-established tradition in Burma and Southeast Asia, many view it as a bedrock notion of the religion. While I do believe, at its core, Buddhist doctrine advocates for an all-encompassing loving kindness and equality for all, I also believe that the tradition can be intolerant of feminine spirituality and that it is not exempt from interacting with politics and cultural norms in the same way other traditions of the world are. In examining and exploring the attitudes Burmese monastics have towards full ordination for women, I hope to illustrate how complicated Burmese Buddhist ethics can be. I will move carefully through my argument, first drawing from primary textual sources to understand the idea of the non-self, then moving into attitudes of monastics toward full ordination and finally, closing with a discussion of karma in Theravada Buddhism.

\section{The Self in Buddhism}

Buddhism has long been thought of by some as a kind of nihilist tradition due to its doctrine of "no-self" (anatta), with Friedrich Nietzsche being one of the most famous and outspoken supporters of this interpretation. While I reject this interpretation, I do want to delve into the discussion of the self as understood by Burmese Buddhists. One of the Buddha's central doctrines or assertions is anatta—-"no self," or even "no soul” (Rahula 1974: 55). During one of my interviews with Candavara, we were sitting on a bridge that overlooked the Irrawaddy River, which had several young children playing and splashing along the shore in its mud. I was consciously asking him about the self and what it meant to him. It was almost a bombardment; looking back on the interview now, I can recognize that I was frustrated, confused, and struggling with this contradiction. I needed new insights in order to feel satisfied. I 
wanted to know why women had to wear different kinds of robes if the texts say that the "I" underneath those robes is nonexistent: "the idea of self is an imaginary, false belief which has no corresponding reality, and it produces harmful thoughts of 'me' and 'mine'” (Rahula 1974: 51). I wanted to know why gender seemed to be important, even though the Pali canon describes the body as a mere "heap of bones covered with flesh and besmeared with blood under the shadow of decay and death” (Bodhi 2005: 143). I wanted to know why the material (the physical form of the body) was having such a large effect on the immaterial (one's capability to practice advanced forms of spirituality). In the middle of the interview, he stopped me and directed me to look at the children along the shoreline below. He said, "Look at the children playing in the mud. Sometimes, water can make you dirty. Sometimes, water is what you use to clean yourself. Sometimes your mind can make you dirty and other times, your mind cleanses you. Right now, your mind is making you dirty” (Candavara 2015). After this, he refused to answer any more questions about the self. He was essentially saying that trying to use Buddhist texts as a means to argue for a reinstatement of the bhikkhuni lineage was making my mind dirty, and thus was a thought worthy of accruing negative karma. This is reminiscent of other interviews I had with monks regarding the status of women in Burmese Buddhism. Discussing a traditional and close reading of Buddhist texts was encouraged and enjoyed by them, but not if I was using it to point out contradictions or justify full ordination for women.

In order to discuss these contradictions more fully, we must distinguish between conventional and ultimate truth. To be clear, I am not a scholar of Buddhist 
Theology, nor do I consider myself worthy of being able to tell Buddhists how to practice Buddhism. I am merely inquiring how Burmese Buddhists justify the lack of lineage for women in light of these contradictions. Conventional truth (sammutisacca) is what we are adhering to when we say things like "I," "you," or "we.” We are not lying when we say these things, but rather conforming to the truth of the conventional world we live in. This truth, however, lies on a rung just beneath ultimate truth (paramattha-sacca), which tells us that there is no "I" or "individual" in reality (Rahula 1974: 55). Buddhists in Myanmar-Burma are adhering to conventional truth when they refrain from allowing full ordination for women because the ultimate truth does not include ideas of gender or sex, but rather ideas about the nature of existence, which should be mentioned only in designation, but not in reality. To further solidify that there is no self, and any attachment to the idea of one is outside of the Buddha's teaching, I turn to three important verses in the

\section{Dhammapada.}

As mentioned earlier in this thesis, this text is well known in MyanmarBurma. Verses five, six, and seven of chapter 20 are extremely important in order to understand the no-self teaching. The first two verses read "All conditioned things are impermanent,” and “All conditioned things are suffering.” The third verse, by contrast, states “All dhammas are without self,” (Woodward 1921: 69). In the first two verses the word samkhara, or the word for "conditioned things," is used. In the third verse, however, it is replaced by the word "dhamma.” The term samkhara ${ }^{18}$ is understood to designate the five aggregates (matter, sensations, perceptions, mental

\footnotetext{
${ }^{18}$ It is interesting that the word "khanda" is not used here, which is the more standard term for the five aggregates, and samkhara is, though it is a term with many ritual and material meanings.
} 
formations, consciousness) including all things that are conditioned, be they physical objects or mental states. If the third verse had used the word samkhara instead of the word dhamma, one might be able to assume that conditioned things are without self but beyond conditioned things, there lies a self that could exist. Because the text chose dhamma, I feel there can be no confusing the idea of anatta in Buddhism and furthermore, no confusing the idea of anatta in Burma as this text is often read closely by monastics. No matter whom I interviewed in Myanmar, layperson, monk or thila-shin; they all agreed on the no-self doctrine. The reach of the word dhamma is much farther than the word samkhara, and removes any uncertainty on the matter. There is no term wider than dhamma in Buddhist terminology (Rahula 1974: 58). According to Theravada teachings, there is no self inside the individual or inside the dhamma.

This teaching, perhaps more than any other in Buddhism, seems to support the idea of equality for all. Not only are we all the same, "we" are not at all. This brings us to a kind of philosophical paradox: in some way we inhabit a physical body, but in another way, we are not there to inhabit it. Even so, when Theravada Buddhism declares who can be a Buddha and who cannot, the texts make clear that a woman cannot be a Buddha and only a human who enters this world inhabiting a male body may achieve this feat (Bodhi 2005: 251). Texts do declare that women, anyone for that matter, can become an arahant (Katz 1982: 180). However, these declarations have established a gender hierarchy that adheres to the very (conventional) truth that Buddhist texts claim to be harmful in the ultimate quest for liberation. If there is no self, than the possibility of an individual being better equipped to attain Buddhahood 
than another based on physical aspects of his or her non-self does not seem consistent with the rest of the teaching.

Contrary to popular notions, the Buddha did not advocate for the abolition of the Indian class system and attempt to establish a classless society (Bodhi 2005: 113). Within the sangha, rather, all class distinctions were meaningless and these caste distinctions were rescinded at the moment of ordination. As the texts show, the Buddha argued that liberation was achieved through conduct not birth, and yet, he maintained gender binaries that still affect the lives of spiritual women today. The hierarchies of gender established in the monastic code of conduct and by the idea that only a male can attain Buddhahood have a lasting effect on the attitudes of the Burmese toward a revival. In the same way that he accepted the provisional reality of caste (in the world but not in the sangha), he also accepted it of gender but perhaps even more so as he allowed gender hierarchies. It seems gender is accepted at a different level, not simply that of provision. The provisionality of truth does not make it untrue and the conventional and ultimate truth seem to always be held in tension. One cannot completely trump the other.

\section{Attitudes of Monastics toward a Revival}

Monastics in Myanmar, including some women, do not look to the scriptures in order to prove or disprove the legitimacy of the decision to keep women from fully entering the sangha. This is crucial to understanding the place of the thila-shins. "That's just the way it is," is a phrase I heard very often from those I interviewed in reference to the status of women (both in regards to the thila-shins and in the way laywomen are unable to enter certain temples or pagodas due to their gender). Daw Nang, a 
successful English teacher in Mandalay and the mother of five daughters says "We just accept it, it comes easily to us as women [to be beneath men in the religious realm], we do not bother with it. Women cannot become the Buddha” (Nang 2015). Though she is not a monastic, I use her quotation her here for two reasons: because of how similar her answer is to that of my interviewees who had decided to renounce and because it was difficult to get thila-shins to speak on this issue. Some of them would not answer my questions or reported not thinking about it at all. When I asked the nuns I stayed with at Thila Nyunt nunnery in Sagaing if they would ever want to wear the saffron robes (the robes of a bhikkhuni), many of them giggled in embarrassment. Keyladi, a younger nun of just 14, grinned widely while bringing her hands to her mouth and said, “Only for monks!” (Keyladi 2015). This is not something they think about often nor do they see it as a possibility. The head nun at Sakyadhita nunnery, one of the most prestigious nunneries in Sagaing, possibly in the whole of Myanmar, said "the thought has never crossed my mind," when asked whether she has ever considered full ordination. ${ }^{19}$ When asked about Reverend Saccavida’s journey to Sri Lanka to be ordained and her subsequent defrocking after the traumatic event she went through in a Burmese prison, she simply said, "Yes, I have heard, but I do not discuss politics.” This is a nun who, relatively and compared to most, exercises a great deal of power. Sakyadhita is a school as well as a nunnery, and they only accept gifted nuns who are willing to study the dhamma vigorously. If even the most educated and influential thila-shins in Myanmar refrain from simply

\footnotetext{
${ }^{19}$ This interview was rather quick, and any talk about full ordination for women was not well received and clearly made the head nun uncomfortable.
} 
thinking about full ordination, the attitudes of thila-shins toward a revival are somewhat difficult to discern.

There are many ways to assess this indifference. We could take it as a function of the deeply ingrained gender binary along with the Head nun's satisfaction with her place in Burmese Buddhism. Granted, the Head nun of Sakyadhita certainly has the time and space to practice Buddhism in the way most nuns do not, and as we have seen, many thila-shins desire full ordination not for equality, but for a deeper opportunity to practice their tradition. We know also that thila-shins are revered the more modest they are, and this precludes being outspoken or going against the religious ministry and its leaders. Against the backdrop of a changing world, nuns find new meaning in preserving many of the traditional values and implications of what a Myanmar woman should be (Kawanami 2013: 92). I feel it may be useful to refer to Butler's (1993) notion of the "paradox of subjectivation,” here. Agency is located as a "reiterative or rearticulatory practice, immanent to power, and not a relation of external opposition to power" in this notion. In other words, the same conditions that solidify a subject's subordinate position may be the means by which they start to think of themselves as a self-conscious agent.

In the same vein, through this indifference we may start to realize the complications with superimposing liberal feminist frameworks on the everyday lives of Buddhist nuns in Myanmar. It is not the aim of this thesis to misinterpret renunciant narratives of women in order to support a theoretical framework of transnational feminism, which is why the quotation of the Head nun is included. I feel using this framework could neglect the everyday concerns of thila-shins if one is not 
extremely careful. I found that those everyday concerns do not always-sometimes never-include worrying about their ordination status. Talal Asad (1993: 289-90) makes the argument that those actions which are part of everyday life tend to be left out in the representations of cultures: "Everyday life is not so easily invented, abandoned, reinhabited, as this notion of culture...suggests... Life is essentially itself. Only the part of it that can be narrativized may be said to be 'made-up' like a story by an artist.” An examination of any gendered subject and its relationship to notions of autonomy, agency, and resistance must be done with the utmost care. In some way, all narratives rendered about subjects researched is exactly that: a rendering, a construction that may speak more to the discipline it writes within than to the human subjects whom it writes about. This, too, is a rendering of how thila-shins in Myanmar live their lives.

In performing this research, I started to wonder about the way the female renunciant is conceptualized. This is important in order to understand the attitudes of monastics toward a bhikkhuni order for thila-shins: the actual concept of female renunciation in Myanmar is riddled with contradictions (much like her ambiguous religious status). When a woman renounces, she can be seen as a beggar and greedy because she is neither monastic nor productive householder, but her simple way of living is respected. Those close to her will view her decision as admirable or daunting (or both). ${ }^{20}$ Her ability to adhere to the precepts is questioned as well as her motives for renouncing. She is expected to be modest, but assumed to be sexually deviant. All

\footnotetext{
${ }^{20}$ When asked about the difference between a family's reaction when a boy versus a girl decides to renounce, Panna Jota answered that "it's not the same for girls, people don't want their daughters to be nuns because it means they will have to support them [instead of a husband].”
} 
of these contradictions stem from traditional textual and social notions of a gender binary; they are not historically constructed by women themselves.

Female renunciants and their religious aspirations are understood, repeatedly, as spiritually inferior. Of the few monks I spoke to who challenged this idea, one of them alluded to the fact that their inability to be ordained was not simply a decision of the sangha, but of the government. Panna DiPa, another teacher at Sitagu International Buddhist Academy with Candavara, said (of monks and nuns), "I believe they should be equal. It is mostly about respect. Life is hard for thila-shins because they don't get any respect or support. If they were ordained, they'd be able to attend the recitation of the Pattimokkha but now they can't, so even if some of them wanted to follow all the rules they can't because they don't know them. The religious leaders in the government don't want them to be ordained” (Panna DiPa 2015). This suggests that monastics' attitudes toward a reinstatement of the lineage do not matter in the larger picture. Panna DiPa alludes to the fact that if the religious leaders wanted a bhikkhuni order, they would allow one. Panna Jota agrees. He asserts, “according to Buddhist Literature, bhikkhunis should be here [part of the sangha], but the Religious Ministry doesn't want it. In the time of the Buddha, the nuns lived close to the monks. I think thila-shins should read more, expand their minds, and get the right view. Thila-shins are much more diligent in following the rules.” Panna Jota seems to believe the opposite of some of his equals in regard to a woman's ability to follow the monastic code, but perhaps more interesting is his and Panna DiPa's mention of education and familiarity with Buddhist texts. 
Thila-shins, especially poor thila-shins, do not always have access to education in the same way that novices or monks do. Some of them will not attain a high school level of education let alone become learned in important Buddhist texts. I met many young nuns who had never heard of, much less read, the Therigatha. The International Buddhist Academy in Sagaing, for example, is home to hundreds of monks. Monks and/or novices are allowed to live there while they study and/or teach. Thila-shins, on the contrary, while not barred from attending the academy, are not allowed to live on the grounds. Candasiri, who lives twenty miNutes by foot from the academy, is able to attend because the distance is short enough for her to walk. Other thila-shins, however, are not so lucky. If Candasiri would have to pay for a ride to the academy, she would not attend due to lack of monetary funds. She already finds it difficult to pay for her textbooks, notebooks and writing materials, blank computer sheets to print her term papers on, and other supplies. Though she is close to finishing her MA degree, she recently had to take leave from school because she could not afford it and is saving money until she can begin again next term. As stated earlier, life for a thila-shin can be difficult, and pursuing education is not an easy, if viable, option and possibly not even a priority. Even so, many times the level of education thila-shins have is used to justify their place outside of the sangha, even though it is this position exactly that causes education to be complicated to attain.

There is more to the story here. Though Panna Jota and some other monks I interviewed could be seen as allies to spiritual women in Myanmar and their quest to pursue Buddhism, there is still an understanding that women pose a possible hindrance to the spiritual path for men. Panna Jota, when talking about jhana 
(meditation), said, "If you are in jhana or want jhana, you shouldn’t talk to women" (Panna Jota 2015). A novice from New Masoeyein Monastery who preferred not to be named said, "Our teacher instructs, 'Woman is the most dangerous thing. Woman is tempting." These two statements speak to the structural hierarchies and narratives that surround the nature and qualities of women embodied in the Burmese Theravada tradition. They also speak to the lack of recognition of homosexuality, or the idea that to some men, other men may be tempting. ${ }^{21}$ While it is not hard to understand that perhaps sexual desires and/or close proximity to that which one sexually desires (whether it be a woman, man, or other) would be a hindrance toward any kind of spiritual path, it is hard to understand why only one possible object of sexual desire would be painted as the most dangerous. As mentioned in chapter two, sex or sexuality (and an attachment to it) seems to be the problem here, not women. Surely the consequence of teaching both young novices and thila-shins that women are among those things that are the most dangerous is dire. It affects not only how monks view women, and how laymen are taught to view women, but also how nuns and laywomen are taught to see themselves, their character, and their moral status/capacity compared to men.

There are Numerous negative narratives applied to thila-shins that have documented effects on their psyche and self perceived abilities toward their spiritual progress (Kawanami 1993). It can be argued that the insecurity of their religious position drives them to make far more efforts in observing the rules and regulations.

\footnotetext{
${ }^{21}$ Homosexuality was a virtually untouchable topic in almost all of my interviews. After numerous meetings and conversations, Panna Jota briefly mentioned a part of town where "the gays" like to go (Panna Jota 2015). This was the only time during my fieldwork that a member of the sangha acknowledged that there was such a thing as homosexuals/homosexuality.
} 
Even those monastics who believe the bhikkhuni lineage is a right of the Buddhist women of Myanmar, still perceive and speak, whether subconsciously or not, about women as spiritual impediments to men.

Still, the fact remains that several monastic informants referred to the government or Religious Ministry as the real cause for the lack of bhikkhuni lineage. Furthermore, when discussing efforts of Burmese women to reach full ordination, the Head nun at Sakyadhita claimed she did not discuss "politics," as if any talk of a revival was political in nature. Most monks that I interviewed seemed sympathetic to the plight of the thila-shin, but ultimately acted as if it was not their battle. I got the feeling that if the revival were to happen, that would be fine, but it was not their responsibility to reinstate it. Few spoke of the reason for government opposition, and my instinct is because it would require placing either Myanmar or monks in a negative light. Full ordination for women would either require the monks to share the funding the government provides for them with the thila-shins, or double the amount allotted, the head monks oppose the former while the government opposes the latter.

\section{Karma and a Revival}

Buddhist texts clearly state, as I have demonstrated, that there is no self and that attachments to thoughts or ideas about the self can be harmful. I am arguing that keeping women from full ordination is inconsistent with the texts because it is an attachment to physical and material aspects of the world and attachment to these kinds of thoughts can produce negative karma. Harvey, a scholar of Buddhist ethics, asserts that actions must be intentional if they are going to generate karmic fruits (2000: 17). The intention of the Religious Ministry in their 2004 decision to reaffirm 
their position on the bhikkhuni lineage was to keep women from entering the sangha. This is not congruent with what Harvey lists as the Buddhist perspective of how one should treat others, the most important of which (for the task at hand) is Number four: "Impartial treatment: all have the potential for nibbana, in this or a future life, and all bring themselves into their situations, good or bad, by their own karma. Thus all should be viewed with equanimity and impartiality" (Harvey 2000: 17). Perhaps more importantly though, I feel that the decision could be seen as possessing the criteria for a "bad action." Buddhist texts give a criteria for differentiating between good and “wholesome actions," as opposed to "unwholesome” actions.

The criterion for a "wholesome action" is of three kinds: the motivation behind the action, the direct effects of the action in terms of causing suffering or happiness, and the action's contribution to spiritual development, culminating in nibbana (Harvey 2000: 46). This last criterion is key, as the decision of the Ministry opted to make it harder for women to make spiritual contributions and reach nibbana. The other two are relevant as well, though. If an action is assessed in terms of whether it causes suffering or happiness in others, surely this decision did not cause happiness for all. And while it would be hard to argue that it caused suffering for all, several of the thila-shins I interviewed did report that they would love to fully ordain if the chance were given to them and feel spiritually inadequate due to their lack of full ordination. At least for some, this did not cause happiness. Furthermore, one of the possible motivating roots behind an unwholesome action is acting out of delusion or "spiritual misorientation" (Harvey 2000: 47). One could make the argument that the Ministry is acting out of a "spiritual misorientation" and neglecting to see the 
whole truth: that of the irrelevance of the physical form in the quest to liberation. The Buddha urges that one should reflect deeply before, during, and after any action of body, speech, or mind to consider whether the action might harm oneself, others, or both. If one finds that it will bring suffering (dukkha), one should refrain from performing the action. A likely argument by the Ministry would be that, in reaffirming this decision, they were following a law laid down by the Buddha himself and thus following the dhamma. In Chapter 1, I have argued against this.

Referring to how an action is assessed in terms of the contribution it makes to spiritual development can be helpful for the argument I am attempting to make. An action is unwholesome if it leads to more unwholesome states arising, including causing liberating wisdom to be weakened (Harvey 2000: 48). How else can we understand the decision of the Ministry? It did not contribute to the improvement of character, in either those who were affected by the decision or in those persons who performed the action, and it did not assist in moving any person along the Path to nibbana. ${ }^{22}$ Refusing to allow a reinstatement of the bhikkhuni lineage in MyanmarBurma could be argued as being an "unwholesome" action and thus worthy of accruing negative karma.

\section{Conclusion}

In exploring the idea of "no-self" in Buddhism, examining the attitudes of Burmese monastics toward full ordination for women, and discussing karma in Theravada Buddhism, I have attempted to demonstrate how the unethical nature of disallowing

\footnotetext{
${ }^{22}$ If we follow Panna Jota's logic, though, one could argue that the decision may have made it easier for the men in the sangha to move along the path to nibbana. I reject this argument due to my explanation that the enemy in Buddhism is an attachment to sex and barring women from the sangha does not eliminate that attachment.
} 
women to fully ordain in Myanmar is more than just a concern for women. The act itself is one that meets the criterion for an action that is "unwholesome" and thus implicates all who support it. Regardless, it has also been made clear that a close reading of the Buddhist texts or an understanding of the vehicle that is karma is typically not used in legitimizing or delegitimizing the absence of the bhikkhuni lineage. Politics, cultural traditions and gender norms are all intermixing with Burmese Buddhism here in a way that can be paradoxical and hard to understand. What is easy to understand is the need for still more work to understand the female renunciant in Myanmar and elsewhere: her motives, her desires, her everyday concerns. 


\section{CHAPTER 4}

\section{Unexpected Conclusions: Thila-shins' Spheres of Agency}

\section{Introduction}

While this thesis would have been easier to write if the everyday concerns of a thilashin included ordination status, it would not be half as interesting. If conducting fieldwork has taught me anything at all, it is that you cannot plan for what you're going to uncover, you must follow the directions your research takes when you get on the ground in foreign territory, regardless of how far it diverges from your original plan or assumptions. I expected each thila-shin I interviewed to be more passionate than the last in regards to her ability to become fully ordained. I expected the topic of full ordination to be a frequently discussed issue among thila-shins. I did not expect to uncover positive aspects to the lack of full ordination for Burmese Buddhist nuns. I did not expect to temporarily ordain as a thila-shin myself, which altered both my relationship to and the outcome of the research. This chapter, along with exploring the daily activities and everyday concerns of a Burmese Buddhist nun, will cover the positive aspects of the liminal position the thila-shins occupy, my own experience as a thila-shin in Myanmar and the form of agency and freedom a Burmese Buddhist nun is experiencing.

I have mentioned Candasiri frequently in this thesis but have neglected to describe our first meeting. Her acquaintance and subsequent friendship changed the entire course of my research. I met her, walking with one of her friends and fellow thila-shins (who lives at an adjacent nunnery but not the same one as Candasiri), on U Bein Bridge on a sticky, sunny afternoon in June. Both of them had been returning 
from a long day of collecting donations from some of their benefactors who happened to live on the other side of the mile long teak bridge. Their arms were filled, neither had a free hand, they were both carrying two large bags filled with an array of things like raw rice, vegetables, canned soda drinks, some money, and notebooks.

Here, it is important to note that it is customary for monks to have one main benefactor who supports them and makes large contributions to them (something like once a month), while thila-shins can have many benefactors that make smaller donations. This means that they have to make considerably more journeys to visit these benefactors, taking away from their spiritual practice. Offerings and gifts can be given sporadically, but some transactions can develop into long-term commitments. For monks and nuns in Myanmar, it is essential to secure regular donors if one is to contiNue a whole-hearted devotion to the otherworldly matters of the Buddhist tradition. However, it is not so straightforward or simple to find committed sponsors to start with, and it is even harder for a nun to find regular support (Kawanami 2013: 132). The relationship Candasiri and other thila-shins maintain with their benefactors is fundamentally different from that of a monk with his because of the unofficial nature of a nun's religious status. I fear that this thesis may sound repetitive by contiNuously bringing up the things that are different for a thila-shin because she is not a bhikkhuni. Then again, this is one its main points: to demonstrate the multitude of ways that the lack of full ordination affects a thila-shin whether she desires to be fully ordained or not. Their relationships with these benefactors are greatly affected by qualifications and even personality traits of a nun, such as her level of education, her nunnery's reputation, her possible affiliation with a monastery, her family's social 
status or background, and even whether or not she has charisma. All of these things can be factors in a potential donor sustaining a long-term relationship and becoming a consistent benefactor for a thila-shin.

In addition to this, benefactors often expect something in return for their offering to a monk or nun, whether it is something tangible or simply moral recognition. A lay donor's identity is intertwined with the offering he or she gives to a monk or a nun and a public acknowledgement of their donation is regarded as a significant part of the interaction (Kawanami 2013: 134). During my fieldwork I noticed that monks would repay donations by giving a talk on Buddhist doctrine or performing a ritual. This, however, is problematic for a thila-shin as her theoretical worldly status confines her and leaves her unable to perform the same kind of "reciprocation" as a monk. (It should be noted that the donations a benefactor gives differ from the alms collecting I described in Chapter Two.) This results in a kind of pressure to "pay back" the gift. In theory, a thila-shin has no obligation to reciprocate a donation, but in practice, she becomes caught up in the reciprocal mentality. This is difficult to explain, but basically a nun becomes weighed down with moral guilt when accepting donations because of her ambiguous status. This can manifest into a sense of worthlessness and compromise her religious standing in her own mind because she contiNues to worry about worldly matters instead of spiritual ones. In her case, the "unreciprocated gift" does not bring liberation as it might for a monk; on the contrary, it becomes the very source of obligation and burden (Kawanami 2013: 134).

This is an example of an everyday concern for a thila-shin. Securing the means for contiNued spiritual practice can be stressful and time consuming. For 
Candasiri, visiting her benefactor(s) means securing some form of transportation from her nunnery in Sagaing to the bridge (which sits in between Mandalay and Sagaing), walking across the bridge and back, and securing transportation home (and this is only for one of her benefactors). It is a task that can occupy an entire day, can be expensive and possibly cause her to miss any classes she may be enrolled in. She does not complain about these trips, on the contrary, they are what allow her to contiNue living a spiritual life even if they do impose a kind of moral guilt.

Contrary to the thila-shins I had met before her (very few, this was during the first week of fieldwork), she was vocal and willing to discuss full ordination for women among other issues that had seemed untouchable. After talking at length on the bridge, she invited me to come to a talk that was being held the next morning at Sitagu, the International Buddhist Academy in Sagaing, by the Ven. Ashin Nyanissara (the Chancellor of the Academy and a well-known monk of Myanmar). This would not be the last talk I was invited to. Dhamma talks by prominent bhikkhus hold great significance for thila-shins. Several times I insisted that I did not fully understand Burmese but was informed by Candasiri and other thila-shins from her nunnery that it did not matter, just being in the presence of these important men was beneficial and meritorious even if I did not understand what they were saying. Dhamma talks provide a space for thila-shins to be instructed on Buddhism in a way that they seldom experience unless they are enrolled in a prestigious nunnery (which most nuns are not because there are few). In my opinion, it is for this reason that the talks are disproportionately full of thila-shins while few novices or bhikkhus can be 
seen. I knew that attending the talk would be beneficial for my research but I was in no way aware of how much it would alter the course of this thesis.

This first dhamma talk was important because it illuminated the way thilashins and bhikkhus interact when they are occupying the same space (not something I had seen yet or saw often in my fieldwork), and it helped me form a relationship with Candasiri. By actually showing up to the talk she had invited me to, something she clearly thought I would not follow through on, I significantly strengthened her trust in me. More than that, she began to see me as more than a backpacker or everyday tourist, and as someone who was genuinely interested in the tradition(s) of her country.

During the lecture, which was a kind of commencement ceremony for students of the Academy and spoken fully in Burmese, the bhikkhus and thila-shins sat on opposite sides of the room with an open space, a middle lane, between them. The bhikkhus were slightly closer to the front of the room and sat on the right side (interesting and possibly significant given what Panna Jota said about wisdom being on the right side). At the end of the talk, they were invited to exit the room before the thila-shins, who waited patiently in a seated position until the very last bhikkhu/novice was out of the room.

I think it is important to state here that feminism is not merely about women despite many thinking it is; it is about relation since we are all living in relation to each other. Much of my research entailed simply watching the interactions and the relations between thila-shins and bhikkhus in an effort to understand the gender order they adhere to, if any. It was and is important that the bhikkhus left the room first. 
Feminism is about these interactions. Feminist thinkers such as Woollacott, Narayan, and Mohanty have consistently pushed for the recognition of the centrality of the gender order to the social, economic, and political order of any given culture. Myanmar, too, has a gender order and it is something that is central to the form Burmese Buddhism takes. Millett (1970) argues that beyond just a gender order, there are sex/gender systems and they sit at the origin of women's oppression. While I do not fully agree that these systems are the only enforcer of women's oppression, I do agree that institutions like religion (in this case, Theravada Buddhism) can reinforce differences between men and women and thus reinforce oppression. This system, defined as "the set of arrangements by which a society transforms biological sexuality into products of human activity," seemed to be playing a large role in the way thilashins understood themselves and their relation to others. I often found myself pondering the question: was gender equality for Burmese nuns best achieved by recognizing the differences between men and women or the similarities between them? This is a driving question in feminist thought, and one that still shapes the movement today.

Significant for me at this first talk and others I attended were the ways in which laymen behaved. At one event in particular, a dhamma celebration for the 700year anniversary of the city of Sagaing, I arrived a little over an hour early with the nuns of Thila-Nyunt to find a spot inside the temple. It was crowded already, with next to one hundred nuns filling the room and around the same number of laywomen present (and more would come). There were very few monks that I could see; I counted twelve, and very few laymen. We were lucky, I was told, to have arrived 
early enough to get a seat close to the stage where a famous monk would be giving a dhamma talk to celebrate the city's anniversary. Almost ten miNutes before the monk was supposed to begin his address, laymen started to file in rapidly. They moved along the sides of the crowd, close to the walls, until they were all the way up to the stage. Then, they started to take their seats in front of the thila-shins who had already been waiting there an hour. There are, in my opinion, few examples that display such blatant sexism as watching several nuns well over 80 years old be forced to scoot back in order to give their seat to (mostly) young men who arrived an hour later than they did to witness the same speech. I was amazed at what seemed like an unspoken agreement: the laymen would sit in front of the thila-shins. It was not discussed, the men simply kept coming in through the doors and walking up to the front and the nuns continued to slide back to make room. The laywomen, however, sat behind everyone in the very back of the large temple. This was something I had not expected. I knew that, socially speaking, thila-shins were below monks but I did not know they were below laymen as well, at least in large congregations such as this one.

This interaction, however, was of no concern to the nuns. When I asked Sandayee why these men were sitting in front of us, she simply answered, "We are making room for everyone to see,” despite the fact that there was plenty of room behind us where the laywomen were taking their seats (Sandayee 2015). Her answer and confusion toward my question made me feel as if I was making a mountain out of a molehill. This happened to me often while spending time with the nuns. Once, I saw Head nun Daw Vannacari, an 84-year-old nun who is well accomplished in the dhamma as well as meditation, struggle to kneel down onto the ground in order to pay 
homage to a monk who was not even half her age. I know this to be a rule in the Patimokkha, but I could not look away. It cannot be overstated; nuns are concerned with advancing their spiritual practice in the best way that they know how, which entails adhering to the gender order. They seem almost not to notice when gendered interactions such as these happen, or at the very least, refused to be or are not fazed by them. By much of Burmese society, there seems to be a trivialization of the pursuits of thila-shins, as if their spirituality is admirable but ultimately not plausible and so they are often treated as less than monastic. The first day I met Candavara, for example, he rudely interrupted Candasiri as she introduced us and, speaking only to me, said, "Her English is not good. She is only a student here, I am a teacher" (Candavara 2015). His genuine smile and peaceful demeanor as he spoke the words were just as surprising as the ease with which he said them. Since that day, I have tried to imagine a thila-shin speaking the same way about a monk who was right in front of her. It would never be tolerated. This is not to say that I think it should be tolerated but it is a testament to the way some monks view thila-shins: as lesser aspirants on the Buddhist path. Candasiri, however, did not miss a beat. She simply nodded and smiled.

This trivialization of the life and work of thila-shins is common. They are often looked down upon, both by society and bhikkhus, for their lack of education (both Buddhist and secular) and their tendency to perform chores such as cooking and/or cleaning. Ironically, they have poor access to education and must perform these chores because of their ordination status. They are looked down upon for not being educated, as discussed in Chapter Two, yet are not given the same opportunities 
as monks and novices to be educated. They are scoffed at for cooking and cleaning, yet perform all the work monks have laywomen or thila-shins do for them on top of daily meditation and fasting. As discussed in Chapter 2, thila-shins project an outward persona of reservedness, modesty, and humility, which may be contributing to an overall perception of them as fragile, perhaps even weak (certainly intellectually/spiritually weak but physically weak as well). When living in the nunnery, I found that this was very far from reality. Buddhist nuns in Myanmar are independent, strong in the deepest sense of the word because they do not have to display this strength, rather they utilize it when necessary. Candasiri was sweating when I met her from hauling heavy bags for over a mile, not exactly a task accomplished by the faint of heart. Keyladi, the younger nun introduced in Chapter Two, was ecstatic to show me how she could drag a twenty pound bag of rice from the entrance to the nunnery all the way into the kitchen when Candasiri and I returned with it from the market. This is shown below in Figure 9. 


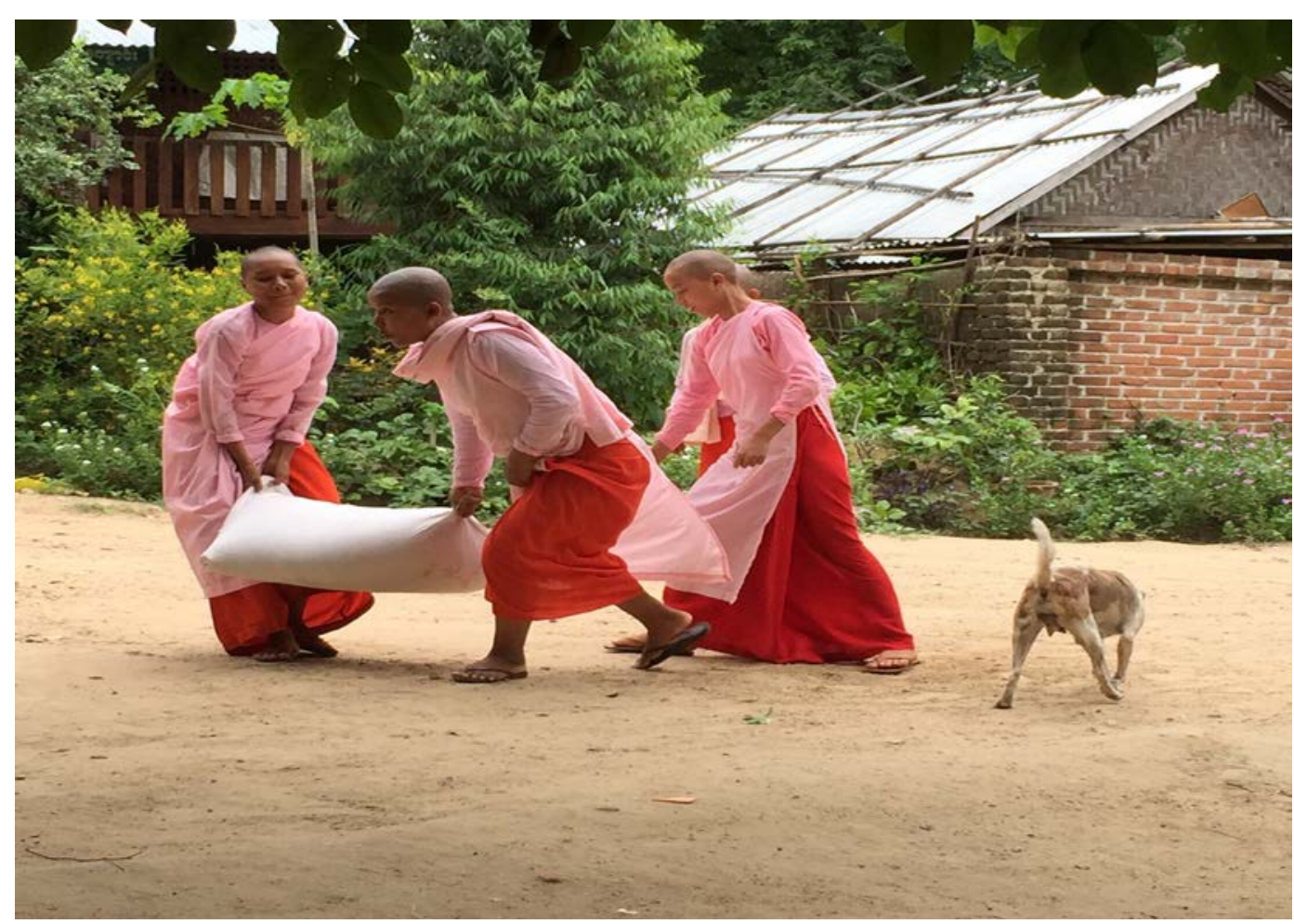

Figure 9. Young nuns of Thila-Nyunt nunnery carrying a donation of rice to the Kitchen

This is a task most monks would never have to do. Not that this task is what makes a person worthy of being called strong, this is just to say that the idea that a thila-shin is fragile or weak is ironic considering what she must do in order to maintain her spiritual lifestyle: often times it is much more than a monk with far smaller a reward.

On the topic of food, contrasting largely to monks, it is a daily concern for thila-shins. It is their responsibility to prepare their meals everyday, and for the nuns of Thila-Nyunt, this includes cooking for the younger nuns as well as the novices who stop by for alms in the morning. This differs from monks, who usually have laywomen or thila-shins themselves prepare their food. I cannot speak for all the monks of Myanmar, but during the course of my fieldwork, I never saw one monk or novice preparing his own food. For the nuns, it seems to be a way to connect and bond. Food preparation seemed to be the most exciting time of day, with the older 
nuns sometimes scolding the younger nuns for getting too rowdy (pictured below in Figure 10).

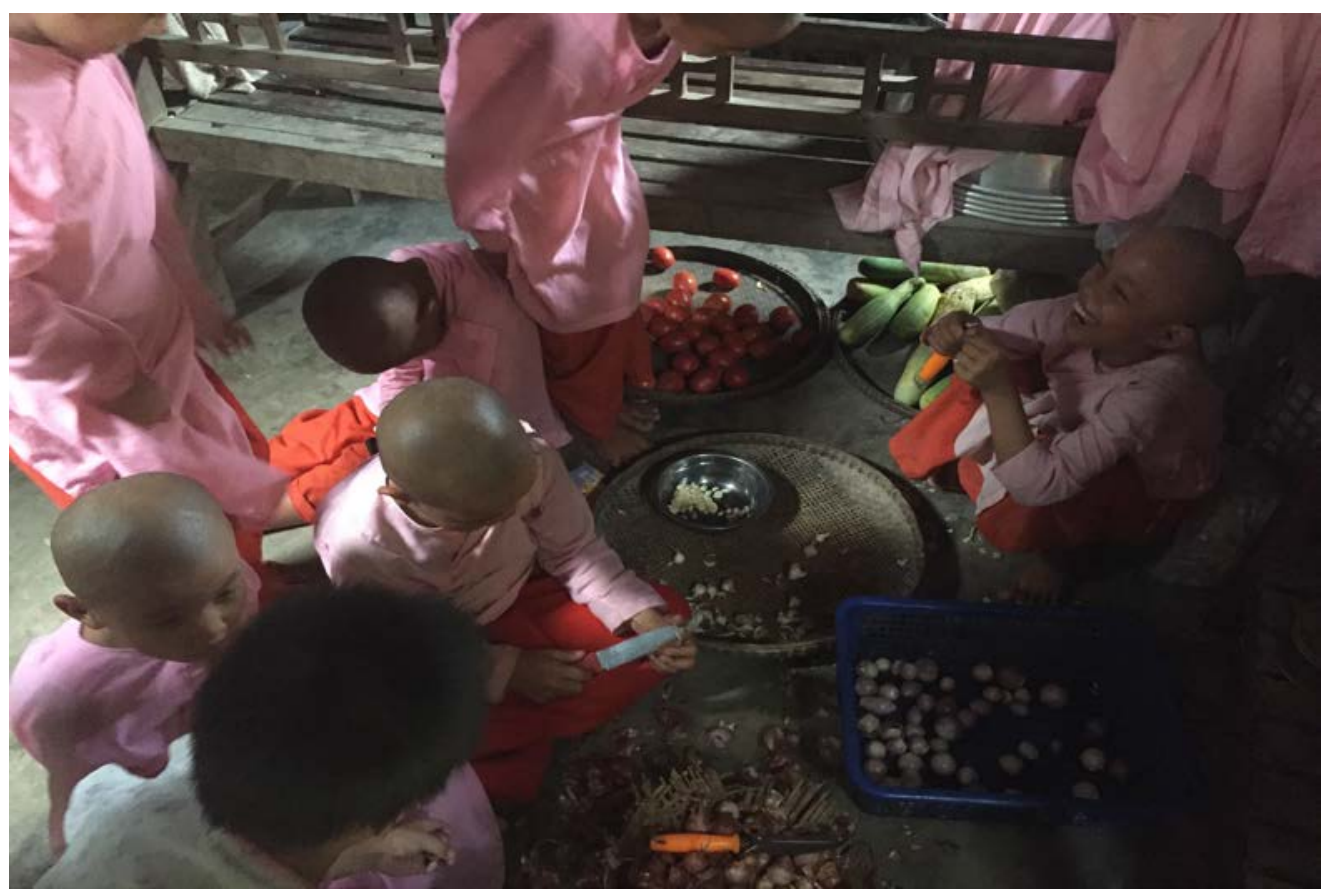

Figure 10. nuns of Thila-Nyunt happily preparing meals for the nunnery

For some reason, there is a trivialization of this work even though the thilashins continued performance of it contributes largely to the overall success of monastic life. It may be useful to draw from Marxist feminism here. Marx stated, "The mode of production of material life conditions the general process of social, political, and intellectual life. It is not the consciousness of men that determines their existence, but their social existence that determines their consciousness” (Marx 1972: 20-21). Marxist feminists will claim that social existence determines consciousness. The observation that a “woman's work is never done” is more than an aphorism to them, but rather a description of the nature of a woman's work. Thila-shins are always on call, but not valued for it, forming a conception of themselves that they 
might not have if their societal roles did not keep them socially, economically, politically, and spiritually subordinate to men.

Marxist Feminists are also trying to place classism rather than sexism as the fundamental cause of women’s oppression (Tong 2014: 93). This is significant as many thila-shins who ordain do so as a response to their economic situation. Close to 80 percent of monastic members come from rural villages or semi-rural towns where their families and kin are primarily engaged in farming or agricultural trade (Kawanami 2013: 64). I do not feel it is accurate to list poverty as a motive for renouncing and becoming a thila-shin, because most nuns who renounce from these rural towns view their families back home as well off. Becoming a thila-shin, though, is perhaps their best bet at receiving education and learning Buddhist scriptures. I did meet many young thila-shins who were orphans and in their case, becoming a nun was without question the best opportunity for them in terms of receiving regular food, shelter, and education. Whether orphans or not, becoming a thila-shin brings a new kind of work. Thila-shins by no means have an easy life even if the environment is one that provides certain creature comforts. Each nun must work for her place in the nunnery. Marxist feminists would argue that the links between a thila-shins work status and her self-image must be analyzed if we are to understand the unique character of her oppression. In other words, women's work shapes women's thoughts and consequently, “female nature,” meaning that the kind of work a thila-shin performs factors into the way she sees herself. 


\section{Thila-shins and Self-Image}

While I do not feel it is necessary or productive for this thesis to go into detail about my temporary renunciation and time as a thila-shin, I will bring up certain aspects that I feel are particularly relevant. Before I temporarily ordained, I was exceptionally interested in the way thila-shins were self-conscious of their bodies. Many of them seemed to have a poor self-image, made all the more relevant given Marxist feminist theory. They seemed to view the work they performed as just as unnecessary as their own bodies, regardless of how important both were and are to the sangha. I began to wonder about this self-image in many ways, but most importantly wanted to discern how a thila-shins negative view of her body connected to her maNual labor if at all.

For my first shower as a thila-shin, taken outside with a bucket, I was fully prepared to remove all of my robes. Candasiri, who was a gracious guide during my stint as a nun, threw her hands up and screamed, "No, no, no, no! Robes on!” She looked simultaneously scared and amused. It was then I learned a thila-shin must never be naked, furthermore, she is never allowed to be naked. This was cumbersome at first. I felt it bothersome to pour buckets of water onto my robes while I showered, try and wash all parts of my body while I was still wearing clothes, shimmy a dry robe over the wet one, scoot the wet one down around my ankles and then wash it after because it had fallen to the dirt and dust filled ground that surrounded the water hole. Days into it, though, and after days of not seeing my body once (there were no mirrors at the nunnery), I started to harbor negative feelings toward it. I was glad I did not have to see it. To be clear, it was not a feeling of insecurity in that I did not like the way my body looked, but more that I felt so despised that I needed a body to 
move about the Earth. I started to see my body as a material thing that was already going through its decomposition, a material vessel that was keeping me from a spiritual journey instead of taking me on one. My breasts especially were uncomfortable to me in a way that they had never been before.

When I tried to talk to Candasiri about this, she praised me for seeing the "true nature of my body.” She started to reiterate to me things she had already said in previous conversations. "Men are clean, women are dirty. Because of our blood and this is the Buddha's teaching. Women have many things to be proud of but we should be patient” (Candasiri 2015). ${ }^{23}$ Because we had spoken about it before, I knew that by saying "we should be patient," an unspoken "until we are reincarnated as a man" was discernable. This happened with Candasiri often, she would say things that seemed to go completely against the way she lived her life. In theory, she seemed to believe that she was less than a man, but in practice she lived her life with just as much agency as any monk I met. This caused me to read her declaration for patience in a different way. Patience is something a thila-shin must practice every single day, for selfpreservation if nothing else.

\section{Thila-shins and Agency}

In spending time with the nuns at Thila-Nyunt, I started to think vigorously about agency. It was clear that these women had agency, that they were agents in the deepest sense of the word. I watched them move about their days, acting differently in

\footnotetext{
${ }^{23}$ Menstruation was a difficult topic to discuss with the thila-shins as the younger nuns giggled abundantly and the more mature nuns acknowledged that they bled once a month but refused to talk further on the matter. It is not productive to do so here, but an investigation into how the menstrual cycle is conceptualized for thila-shins as well as how it fits into their own self-image would be desirable.
} 
different spaces and contexts because they were hyper-aware of their surroundings and the way they wanted to be perceived. Because of their liminal position, nuns in Myanmar live in communities that are not supervised by men. Before Panna Jota came to Thila-Nyunt to assist in my temporary ordination as a thila-shin, no monk had ever been to the nunnery. This, perhaps more than anything else, is indicative of the relationship between monks and nuns. While it is true that some nunneries are in close contact with some monasteries and thus monks, this is not the norm. This is not ideal: in a perfect world, monks and nuns would work together within the Burmese sangha. The fact that Thila-Nyunt had and has little contact with monks, and for that matter, any kind of higher authority in the hierarchy of Burmese Buddhism perhaps solidifies their subordinate position. Not only are they subordinate, they are so subordinate that they are not even regulated.

I want to be careful in this thesis to portray the nuns as agents, as transnational feminism argues against a representation of Third-World women as victims without autonomy or direction. To be clear, I am not portraying them as actors with agency because transnational feminist theory advocates for it, but because it is the case as I saw it. In spending so much time with them and living life as they did, I began to wonder about how agency, in this context, could be theorized. What does it mean to be an agent, to be free? Is having agency connected to being free? Does agency deal with what people are capable of in their own environments? Are we contributions to our life circumstances or products of them? I started to wonder at the possibility of levels or spheres of agency and how having agency in one does not guarantee agency in all. 
Mohanty (2003) suggests that certain narratives by Third-World women operate not through a logic of identification but through one of opposition. If this is so, then a question about the theorization of domination and resistance arises. Resistance, argues Mohanty, clearly accompanies all forms of domination. Resistance, however, is not always easy to identify and can sometimes live inside the gaps, fissures, and silences of hegemonic narratives. Resistance is encoded in small practices: in remembering, in writing, even in small daily tasks. Agency can be located, then, in the day-to-day practices and struggles of Third-World women (such as Candasiri hauling her donations across a mile long bridge in the summer heat). Thila-shins are resisting, are part of a movement, by not pushing for full ordination. In a way, they are rejecting the institution of Theravada Buddhism by going about their daily struggles in their own spaces and communities that are essentially free from any and all male regulation. By contiNuing to practice the tradition in their own way, without recognition or admission from the male monastic community, they are in essence sending a message that mundane historical law cannot hamper their spiritual pursuits. It is a testament to these women that they, knowing that they are "officially" deemed unable to be ordained and thus very unlikely to be liberated, still renounce worldly matters and belongings and turn inward to attain some kind of ethereal success. Thila-shins must know that the fight for full ordination for women in their country would be exactly that, a fight, a grueling uphill battle until the very end as the government has made examples of certain nuns who did take a stand like Saccavida, mentioned in Chapter 2. 
It may be a stretch to say that their resistance lies in their seemingly nonresistance to their situation but I am arguing that their refusal to abstain from pursuing Buddhism despite the imminent cement wall they will encounter is a kind of resistance if not an organized movement. Furthermore, one could argue that a thilashin simply practicing self-love is a kind of resistance. To an outsider, the community of thila-shins can seem docile, cooperative, and above all compliant to their current situation. To me, thila-shins seem to be hovering above the decision of the Burmese sangha. They know the official decision, yes, and yet they contiNue to renounce and wear the robes. This is, in my opinion, the goal of transnational feminist theory: to recognize the different shape women's movements and responses to their situations take in different parts of the world and to validate them as legitimate, powerful developments by the women who are a part of them. I have read countless articles and papers that paint Burmese Buddhist nuns as women who will one day receive their corroboration as true spiritual mendicants once they are granted the ability to become fully ordained, almost unaware of the fact that by stating this, they are implying that these women can only receive such a status from a male-run entity. Sojourner Truth, an extraordinary woman and Black feminist who touched on issues such as intersectionality that would later become central to early twenty-first century feminist thought, emphasized that (white) women's barrier to true power and equality was not outside of themselves, but inside (Tong 2014: 217). For Truth, women seemed to think that to become powerful, they needed the permission of men, while she believed that if one wants power one should take it. It seems that thila-shins, in their own way, are taking their own power. They practice Buddhism in their own way, on their own 
terms. This, if it can be argued to be found, is a positive aspect of the thila-shins' inability to become ordained. The ostracism of thila-shins has resulted in the creation of communities that are full of women, for women, and operated by women. In these spaces, they can exercise a kind of freedom that is difficult for them to find anywhere else. Inside a nunnery, a thila-shin is scarcely worried about her projection of "true" femininity, being modest, or looking pious. I looked on as thila-shins moved about their spaces with pride, sometimes with disheveled robes, and sometimes with loud voices and laughter.

\section{Spheres of Agency}

There is, however, significance in the lack of voice women have in regards to the issue of full ordination, and all monastic issues for that matter. Not one woman was consulted before the decision was made by the Supreme Sangha Council to contiNue disallowing the ordination of women and thus a revival of the bhikkhuni lineage. This brings me back to agency. I am arguing that there are levels, or more accurately, spheres of agency that can be scaled and thus examined for thila-shins. Agency in one sphere does not guarantee agency in another (though it does/may help cultivate agency in another). Figure 11 demonstrates these spheres. The first sphere and most scaled is at the individual level. I would argue that most, if not all, thila-shins have agency at this level. Agency, once produced in this sphere, moves up, grows, and expands (metaphorically but also shown in the diagram) from here. When thila-shins are in contact with one another, in the confines of their own nunnery or social spaces, they have strong agency as well. This is the second sphere. Interestingly, these first spheres have a relationship that the other spheres do not. 


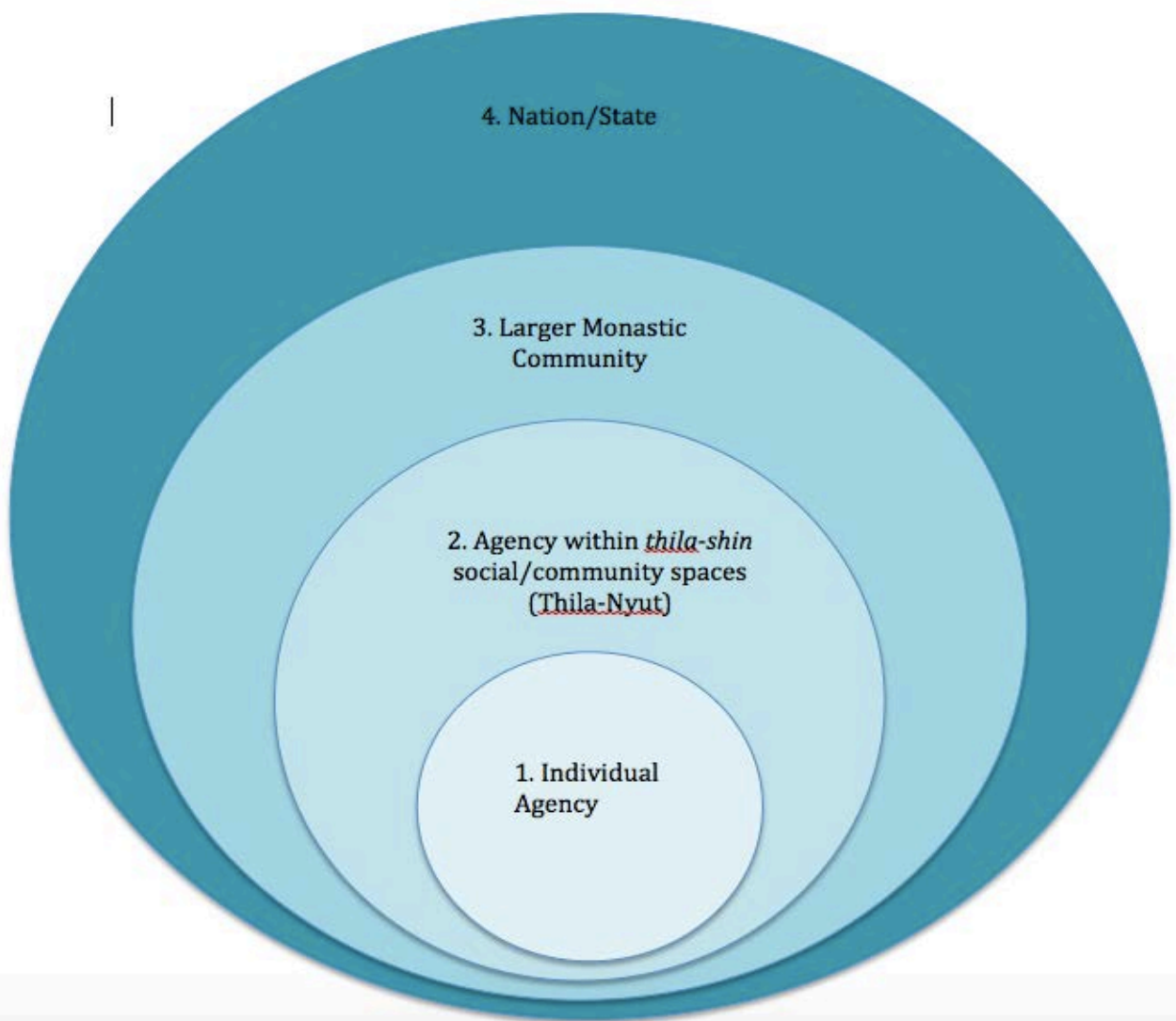

Figure 11. Thila-shins' Spheres of Agency

Some nuns, especially those who entered the nunnery at young ages such as four or five and when they were orphans, perhaps did not have agency when they "decided" to renounce. For this reason, I am arguing that they may have more agency in level two than in level one, regardless of whether they are developing their agency in level one as they mature. Sandayee, for example, was sent to Thila-Nyunt by her mother because her options were clear: work on the farm or become a nun. Opting for nunhood meant Sandayee may have a better chance at education. Sandayee is now twenty years old, has been a nun since she was four, and has just recently started to take classes at Mandalay University. Though she may have not truly known what wearing her thila-shin robes meant when she was merely four, she certainly knows 
now. Outside of these first two spheres, the voices of thila-shins are scarcely heard; it is very hard for them to create change, and it seems that, though they clearly possess agency, they lack political or bureaucratic agency. This is not to say they are unaware or do not want this kind of agency. Sandayee, who has repeatedly sent me messages using the social media outlet Facebook, has requested my help in securing a job for her here in the United States. I mention this to demonstrate that thila-shins have dreams, aspirations, and desires to move up in the world.

This is all in stark contrast to monks, who, I would argue, possess agency in all four of these spheres. Monks are appointed by the government, as discussed in Chapter 2; they thus oversee the larger monastic community along with the Burmese government. In the third sphere then, monks without a doubt possess strong agency, even if some younger monks or novices do not exercise as much of it as older, more involved monks do. Though neither monks nor thila-shins can vote in political elections, I would argue that monks still possess agency in the fourth sphere of Nation-State. The fact that monks work in junction with the government is reason enough to suggest this, but monks also have a comfort and ease with talking about politics that thila-shins do not. Consider the interview mentioned earlier with the Head nun of Sakyadhita. She told me explicitly that she does not discuss politics and essentially refused to comment on anything that might be considered political. Monks on the other hand, freely engage in political discussions. Panna Jota spoke of a place in his monastery that many monks refer to as the "politics tree," due to many congregating there after lunch to discuss current events (Panna Jota 2015). They cannot vote in political elections, this is true, yet monks are considerably more 
involved and even exercise influence in political elections. Take the ease with which Panna Jota had in telling me of the "politics tree," compared to the answer of the Head nun in regards to full ordination. Even if thila-shins did or do think about politics, it would not be something they broadcasted for fear of being seen as even more spiritually incompetent than they are already perceived.

\section{Conclusion}

Is agency a negotiation? Is agency enough? If the culture is not changing, namely, the ideas surrounding femininity and female renunciation in Myanmar, will the law change? As soon as a group of people is fully conscious of itself as a collective social division, it has a better chance of achieving its fundamental goals. Thila-shins, I believe, are well on their way. They have already succeeded in practicing their spirituality in a hostile environment and are exercising their agency within spaces that are seen as subordinate but, as I have shown, clearly possess authority. I have tried to articulate the positive aspects of the lack of full ordination for Burmese Buddhist nuns, something that I never thought this research would entail. In finding these positive aspects and locating agency within the lives of thila-shins, I am all the more excited about their future directions. If this thesis demonstrates anything at all it is the consistency with which women pursue spirituality in Myanmar. Throughout history, and now more than ever, women have opted to renounce in Myanmar-Burma. I sincerely believe that though they are marginalized now, they will not be for long. 


\section{CONCLUSION}

Whether or not we can understand different positionalities, a question posed at the beginning of this thesis, seems to depend on how well we can decentralize ourselves from the topics we study in order to view them from multiple theoretical points in space. I was only able to see the thila-shins as powerful agents after I abandoned my own position. My fieldwork and subsequent research required me to change my positionality, to move about in space and perspective, in order to better examine the issue of full ordination for Buddhist women in Myanmar. There is always a back and forth movement, a conversation, between oneself (who you are) and what one is studying. Learning to disengage with the part of your position that is not serving you could include using multiple points of comparison. I think a full, extensive comparison between the situation for Buddhist women in Myanmar, Thailand, and Sri Lanka needs to be undertaken if we are to thoroughly understand the unique position and political oppression of thila-shins. By comparing (more than two), commonalities reveal themselves along with real, concrete differences that help one to see the state of affairs clearly and from a multi-faceted viewing platform. I often felt, especially when I seemed to magnify gendered interactions that the thila-shins themselves were neither offended nor surprised by, that I was looking at the issue with the wrong pair of glasses and thus, couldn't truly see what was happening. As Mohanty urges, it is essential to remember the micropolitics of context, subjectivity, and struggle along with the macropolitics of global economic and political systems and processes (Mohanty 2003: 237). 
In this context, micropolitics might mean the individual agency of the thilashins or what I have called their own form of "resistance.” In all reality, though, it’s hard to label it as such. Resistance, to me, seems to be a Western or European concept and one that the thila-shins are not interested in. Their actual lived existence would probably not be described as one that is a practice in resistance. Quite the contrary, they throw themselves into their daily lives with a vigor I have scarcely seen elsewhere, they do not resist their socioeconomic position but rather face it head on and handle its consequences with grace. This brings me back to the first sphere of agency in Figure 11: individual agency. To be clear, no one has full individual agency, no one is totally free. Agency is finding a way to be free within the (social, political, economic) constraints that surround you, and the thila-shins are (beautifully) doing just that when they continue to renounce in a country that tells them they cannot fully ordain.

It is no coincidence, in my opinion, that the monks and laypeople refer to Burmese nuns as saya-leis or thila-shins but the thila-shins themselves use the word "nun.” There is no need for resistance when one perceives the desired result as achieved. This is where I would like to lay claim for future directions of research: there needs to be an investigation into the daily struggles, experiences, and lives of thila-shins as merit making struggles and experiences that are not separate from their Buddhist practice even if many (the nuns included) see them as such. Could one refer to Candasiri's lengthy excursion to collect donations from her multiple benefactors as an action that would accrue good karma? It is, after all, an action that contributes to her spiritual practice. Why should we not view everyday practices as religious 
training? This would require getting deeper in to how the thila-shins understand the value of their own practice and experiences. This, regrettably, I did not get a chance to discuss with them. My scholarly stance, in any case, is that their everyday practices should be valued. They are, in my opinion, actions that foster egolessness, spiritual dedication, and seem worthy of accruing good karma. Monks seem to receive more merit by simply existing than a thila-shin does for her consistent struggle to continue cultivating her Buddhist practice. Perhaps her mere existence should also be viewed as a merit making one even if this means structuring the measure of merit differently. Their lived experience, though looking quite different from that of a monk's, is not one that should be dismissed so quickly as any less spiritual. This is not to say it is more spiritual, but rather the labor they are performing is part of their sadhana and should be examined as such. It became increasingly clear the longer I conducted fieldwork that male renunciation and female renunciation look quite different in Myanmar. There is something to be said about the form renunciation takes in different environments and for different people. In this case, female renunciation (while being every bit as legitimate a form as male renunciation in Myanmar) is not being taken seriously.

However, this does not take away from the fact that individual agency only goes so far. The degree of agency the thila-shins have is connected to their daily struggles, which is connected to the levels of agency attained. I have been hesitant to label full ordination for women in Myanmar a political issue. At some point though, I do have to concede that it is, regardless of how artfully the thila-shins have handled their (political, social, economic, religious) “constraints” without engaging in open 
conflict. Government control is in play here, as discussed in Chapter 2; this issue has always been a political one (at least since the government became involved in Burmese Buddhism, if not long before the advent of the nation-state). The current circumstance of any given group of people in a state is always or should always be that state's concern. In this context, I believe that the Burmese government will have to address the thila-shins and their circumstances sooner rather than later as they are only growing in number.

Finally, I would also like to call for an inquiry into those things which the Burmese society exclusively calls on thila-shins to perform. Dhamma talks, for example, are first and foremost an event for monks to lead and facilitate, even though many thila-shins attend. I am interested in finding facets of society (if any) where the thila-shins are the facilitators, where they are the experts in the room. This, of course, is connected to further exploring the value of their particular form of Buddhist practice, and may be found in the fusion of local ritual practices with translocal Buddhist practices. If this thesis has illuminated anything at all, I hope it is the simple fact that Burmese nuns are here to stay and are forging a new Buddhist path. 


\section{REFERENCES}

Asad, Talal. 1993. Genealogies of Religion: Discipline and Reasons of Power in Christianity and Islam. Baltimore: Johns Hopkins University Press.

Assavavirulhakarn, P. 2010. The Ascendancy of Theravāda Buddhism in Southeast Asia. Chiang Mai, Thailand: Silkworm Books.

Blackburn, Ann. 2001. Buddhist Learning and Textual Practice in EighteenthCentury Lankan Monastic Culture. Princeton, N.J.: Princeton University Press.

Bodhi, Bhikkhu. 2005. In the Buddha's Words: An Anthology of Discourses from the Pali Canon. Somerville: Wisdom Publications.

—. 2012. "Can the Theravada Bhikkhuni Order be Re-established? It Already Has.” Saranāloka Foundation, August. Accessed April 28, 2015. http://saranaloka.org/wp-content/uploads/2013/07/bhi-bodhi-can-thebhikkhuni-order-be-reestablished-2013.pdf

Buddhaghosa. 1973. Manorathapūraṇi: Commentary on the Anguttara-Nikaya, Volume 97. Oxford: Pali Text Society.

Butler, Judith. 1993. Gender Trouble: Feminism and the Subversion of Identity. New York: Routledge.

Candasiri. 2015. Interview by author. Sagaing, Myanmar. July.

Candavara. 2015. Interview by author. Sagaing, Myanmar. July.

Cole, Diane. 2015. "You'll Never Guess the Most Charitable Nation in the World.” National Public Radio, November 28. Accessed November 29, 2015. http://www.npr.org/sections/goatsandsoda/2015/11/28/457101304/youllnever-guess-the-most-charitable-nation-in-the-world

Collett, Alice. 2014. Women in Early Indian Buddhism. New York: Oxford University Press.

Daw Nang. 2015. Interview by author. Mandalay, Myanmar. June.

Foucault, Michael. 1976. The History of Sexuality. Vol. 1. France: Editions Gallamard.

Freedman, Michael. 1977. "The Characterization of Ananda in the Pali Canon of the Theravada: A Hagiographic Study.” PhD diss., McMaster University. Accessed December 28, 2015. https://macsphere.mcmaster.ca/handle/ $11375 / 15547$ 
Harvey, Peter. 2000. An Introduction to Buddhist Ethics. Cambridge: Cambridge University Press.

Horner, I.B. 1930. Women under Primitive Buddhism: Laywomen and Almswomen. London: G. Routledge \& Sons.

Jung, Patricia Beattie, Mary E. Hunt, and Radhika Balakrishnan. 2001. Good Sex: Feminist Perspectives from the World's Religions. New Brunswick: Rutgers University Press.

Katz, Nathan. 1982. Buddhist Images of Human Perfection: The Arahant of the Sutta Pitaka Compared with the Bodhisattva and the Mahasiddha. Delhi: Motilal Banarsidass.

Kawanami, Hiroko. 1990. "The Religious Standing of Burmese Buddhist nuns (thilashin): The Ten Precepts and Religious Respect Words.” Journal of the International Association of Buddhist Studies 13, no. 1: 17-39.

— . 1997. "Buddhist nuns in Transition: The Case of Burmese thila-shin." In Indian Insights: Buddhism, Brahmanism and Bhakti, edited by Peter Connolly and Sue Hamilton, 209-24. London: Luzac Oriental.

- 2013. Renunciation and Empowerment of Buddhist nuns in MyanmarBurma: Building a Community of Female Faithful. Leiden: Brill.

Keyladi. 2015. Interview by author. Sagaing, Myanmar. July.

Krey, Gisela. 2010. "Some Remarks on the Status of nuns and Laywomen in Early Buddhism." In Dignity and Discipline: Reviving Full Ordination for Buddhist nuns, edited by Thea Mohr and Jampa Tsedroen, 39-64. Boston: Wisdom Publications.

Lekshe Tsomo, Karma. 1999. Buddhist Women across Cultures: Realizations. Albany: State University of New York Press.

— Achievements. Albany: State University of New York Press.

_ 2014. Eminent Buddhist Women. Albany: State University of New York Press.

Luce, Gordon H. 1969. Old Burma-Early Pagan. New York: J.J. Augustin.

Mahmood, Saba. 2005. Politics of Piety: The Islamic Revival and the Feminist Subject. Princeton: Princeton University Press.

Marx, Karl. 1972. A Contribution to the Critique of Political Economy. Moscow: Progress Publishers. 
Millett, Kate. 1970. Sexual Politics. Chicago: University of Illinois Press.

Mohanty, Chandra Talpade. 2003. Feminism without Borders: Decolonizing Theory, Practicing Solidarity. Durham: Duke University Press.

Mohr, Thea, and Jampa Tsedroen, eds. 2010. Dignity and Discipline: Reviving Full Ordination for Buddhist nuns. Boston: Wisdom Publications.

Narayan, Uma. 1997. Dislocating Cultures: Identities, Traditions, and Third World Feminism. New York: Routledge.

Nissan, Elizabeth. 1984. "Recovering Practice: Buddhist nuns in Sri Lanka.” South Asia Research 4, no. 1: 132-49.

Panna DiPa. 2015. Interview by author. Mandalay, Myanmar. July.

Panna Jota. 2015. Interview by author. Mandalay, Myanmar. July.

Pruitt, William. 2001. The Pattimokkha. Oxford: The Pali Text Society.

Rahula, Walpola. 1974. What the Buddha Taught. New York: Grove Press.

Sandayee. 2015. Interview by author. Sagaing, Myanmar. July.

Sarao, K.T. S., and Arvind Singh. 2007. A Textbook of the History of Theravāda Buddhism. Delhi: Department of Buddhist Studies, University of Delhi.

Spelman, Elizabeth V. 1988. Inessential Women: Problems of Exclusion in Feminist Thought. Boston: Beacon Press.

Spiro, Melford E. 1971. Buddhism and Society: A Great Tradition and its Burmese Vicissitudes. London: George Allen and Unwin.

Tin Maung Maung Than 1993. "Sangha Reforms and Renewal of Sasana in Myanmar: Historical Trends and Contemporary Practice,” In Buddhist Trends in Southeast Asia, edited by Trevor Ling, 6-63. Singapore: Institute of Southeast Asian Studies.

Tong, Rosemarie. 2014. Feminist Thought: A More Comprehensive Introduction. Boulder: Westview Press.

Wijayaratna, Mohan. 1990. Buddhist Monastic Life: According to the Texts of the Theravada Tradition. Translated by Claude Grangier and Steven Collins. Cambridge: Cambridge University Press.

Williams, Liz. 2000. “A Whisper in the Silence: nuns before Mahapajapati?” Buddhist Studies Review. 17(2) 167-173. 
Woodward, F.L. 1921. The Buddha's Path of Virtue: A Translation of the Dhammapada. London: Theosophical Publishing House.

Woollacott, Angela. 2006. Gender and Empire. New York: Palgrave Macmillan. 